\title{
Conflicting $P-T$ paths within the Central Zone of the Limpopo Belt: A consequence of different thermobarometric methods?
}

\author{
M.J. Rigby* \\ Department of Geology, University of Pretoria, Lynwood Road, Pretoria, Gauteng 0002, South Africa
}

\section{A R T I C L E I N F O}

\section{Article history:}

Received 6 November 2008

Received in revised form 13 March 2009

Accepted 13 March 2009

Available online $\mathrm{xxxx}$

\section{Keywords:}

Thermobarometry

Pseudosections

$P-T$ paths

Limpopo belt

Metamorphism

\begin{abstract}
A B S T R A C T
A single metapelitic sample from the Verbaard locality, near Messina was investigated in order to construct a $P-T$ path and moreover, highlight pertinent contradictions in the current $P-T$ database. Interpretations based on $P-T$ pseudosections, garnet isopleth thermobarometry and mineral mode/isopleth modelling indicate that the mineral assemblages, textures and zonations developed in the metapelite formed along a single clockwise $P-T$ path. The metamorphic evolution is characterized by an early high-pressure phase at $10-11 \mathrm{kbar} / 800^{\circ} \mathrm{C}$, followed by a simultaneous pressure decrease and temperature increase to $\sim 8 / 850^{\circ} \mathrm{C}$ and subsequent retrogression via decompression-cooling to $4-5 \mathrm{kbar}$ at $T<650^{\circ} \mathrm{C}$. Growth zoning in garnet provides evidence for an earlier, prograde history, however, as potential melt-loss was not accounted for this must be deemed speculative. The results of this study agree entirely with that of [Zeh, A., Klemd, R., Buhlmann, S., Barton, J.M. 2004. Pro- and retrograde $P-T$ evolution of granulites of the Beit Bridge Complex (Limpopo Belt, South Africa); constraints from quantitative phase diagrams and geotectonic implications. Journal of Metamorphic Geology 22, 79-95], who adopted a similar approach to thermobarometry i.e. pseudosections. The results are, however, inconsistent with recent publications that argue for a twofold, metamorphic history defined by two decompression-cooling paths (DC1 $\sim 2.6 \mathrm{Ga}$ and DC2 $\sim 2.0 \mathrm{Ga}$ ) that are separated by an isobaric heating path $(\sim 2.0 \mathrm{Ga})$. The disparity in the results obtained from different workers can be explained by an examination of the thermobarometric methods employed. The methodology employed to derive the twofold, polymetamorphic $P-T$ path appears to be erroneous. At present, the most reliable and robust method for determining $P-T$ paths is the pseudosection approach to thermobarometry. Future modelling of Limpopo Belt granulites should adopt this strategy and ensure potential melt-loss is taken into account. Alternatively, this potential problem can be avoided altogether by investigating rocks of mafic composition.
\end{abstract}

(c) 2009 Elsevier Ltd. All rights reserved.

\section{Contents}

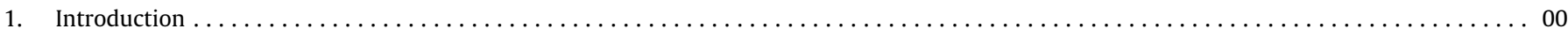

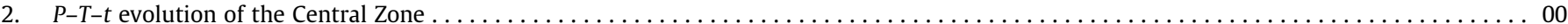

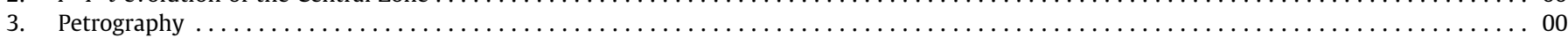

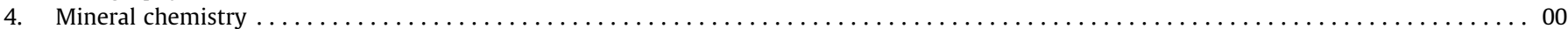

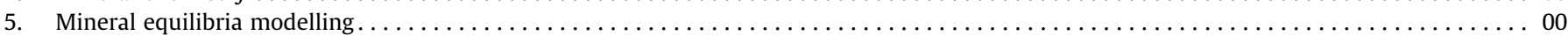

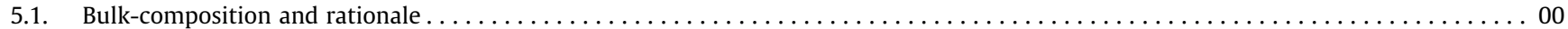

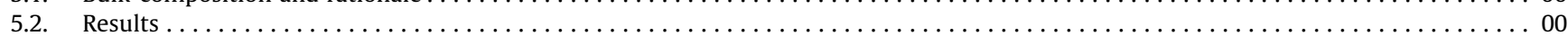

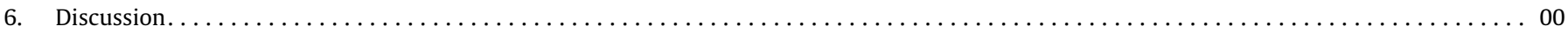

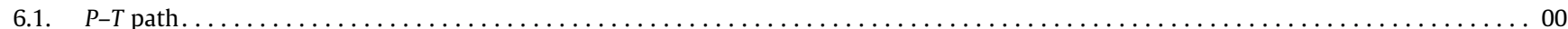

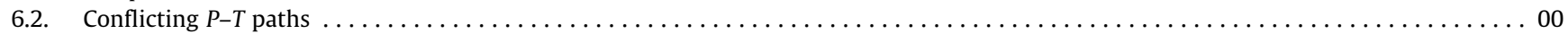

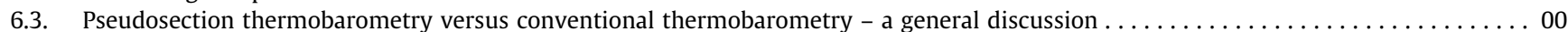

6.4. Pseudosections versus the local mineral equilibrium approach of Perchuk et al. (2008): a method-specific discussion.............. 00

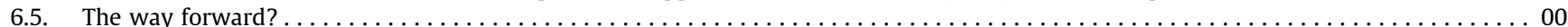

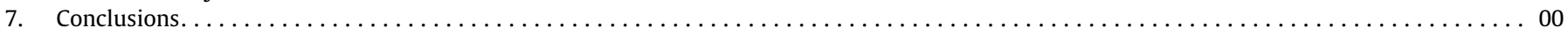

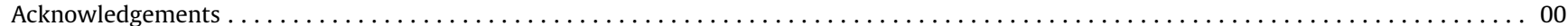

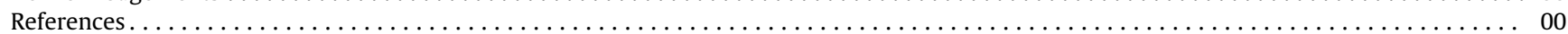

\footnotetext{
* Corresponding author. Tel.: +44 124202456 .

E-mail addresses: martin.rigby@up.ac.za, martinjrigby@yahoo.co.uk
}

1464-343X/\$ - see front matter ๔ 2009 Elsevier Ltd. All rights reserved. doi:10.1016/j.jafrearsci.2009.03.005

Please cite this article in press as: Rigby, M.J. Conflicting $P-T$ paths within the Central Zone of the Limpopo Belt: A consequence of different thermobarometric methods?. J. Afr. Earth Sci. (2009), doi:10.1016/j.jafrearsci.2009.03.005 


\section{Introduction}

The Limpopo Belt of southern Africa (Fig. 1) is an extensive high-grade terrane that can be subdivided into three zones, each with a distinctive geological character and tectono-metamorphic fingerprint (Rigby et al., 2008a). The Northern Marginal Zone (NMZ) is separated from the Zimbabwe Craton by a southwarddipping ductile shear zone known as the North Limpopo Thrust Zone (e.g. Blenkinsop and Mkweli, 1992). Similarly, the Southern Marginal Zone (SMZ) is separated from the Kaapvaal Craton (KC) by the northwards-dipping Hout River Shear Zone (e.g. Van Reenen et al., 1990; Smit et al., 1992). The NMZ and SMZ are commonly regarded as granulite-facies equivalents of the Archean granitegreenstone successions which prevail in the adjacent Zimbabwe and Kaapvaal Cratons (e.g. Du Toit et al., 1983; Van Reenen et al., 1992). Conversely, the CZ forms a lithologically diverse and distinct supracrustal sequence, which includes the Beit Bridge Complex (BBC), a diagnostic supracrustal unit composed of predominantly leucocratic quartzo-feldspathic gneiss, quartzite and marble with intercalated metapelitic gneiss, magnetite quartzite and mafic granulites (e.g. Watkeys et al., 1983; Brandl, 1983; Van Reenen et al., 1990). The CZ also contains several suites of tonalitic, trondjhemitic and granodioritic (TTG) orthogneiss, including the Sand River Gneiss (SRG) and the Alldays Gneiss (AG) (e.g. Van Reenen et al., 1992; Kröner et al., 1999). The CZ is separated from the NMZ and SMZ by two major, ENE-WSW trending, inward-dipping, strike-slip shear zones, the Palala-Sunnyside (PSZ) and Magagohate-Triangle (MSZ) (e.g. Van Reenen et al., 1992; Kamber et al., 1995).

The metamorphism developed in the marginal zones is characterized, undisputedly, by a single, granulite-facies, tectononometamorphic event that occurred in the Neoarchean (Stevens and Van Reenen, 1992a,b; Kreissig et al. 2001; Blenkinsop et al. 2004). Whereas, the relative timing, style and extent of metamorphic activity in $\mathrm{CZ}$ has, over the years, come into question by numerous workers (e.g. Harris and Holland, 1984; Droop, 1989; Hisada and Miyano, 1996; Jaeckel et al., 1997; Holzer et al., 1998; Kröner et al., 1998, 1999; Smit et al., 2001; Van Reenen et al., 2004; Zeh et al., 2004; Zeh et al., 2005a,b; Hisada et al., 2005; Boshoff et al., 2006; Zeh et al., 2007; Rigby et al., 2008b; Gerdes and Zeh, 2009; Van Reenen et al., 2008; Perchuk et al. 2008) who have defined different $P-T$ paths. This has ultimately led to a great deal of controversy surrounding the tectonic evolution of the Limpopo Belt (Rigby et al., 2008a).

Traditionally there have been two contrasting schools of thought regarding the tectono-metamorphic evolution of the $\mathrm{CZ}$. One camp argues that the data collectively indicate that the $\mathrm{CZ}$ underwent deformation and metamorphism at ca. $2.0 \mathrm{Ga}$ (Kamber

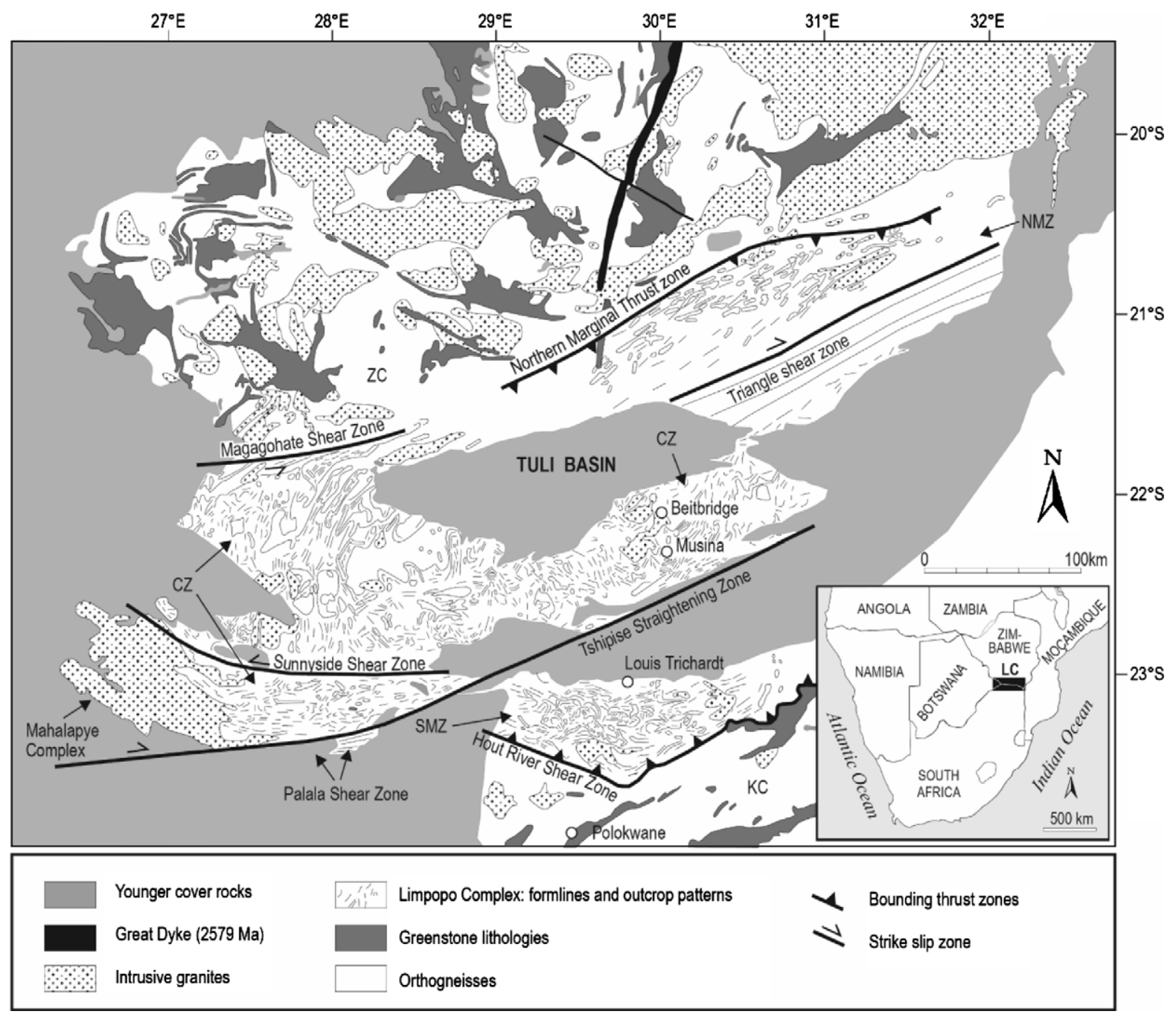

Fig. 1. Regional geological map of the Limpopo Belt (Boshoff et al., 2006). 
et al 1995; Holzer et al, 1995; Holzer et al., 1998; Kroner et al. 1999; Schaller et al. 1999; Zeh et al. 2004; Zeh et al., 2005a,b; Eriksson et al., 2009). Conversely, Van Reenen et al. (1987), McCourt and Vearncombe (1992), Roering et al. (1992), McCourt and Armstrong (1998), Bumby et al. (2001), Bumby and Van der Merwe (2004) advocate that the $\mathrm{CZ}$ and the entire Limpopo Belt formed during a single, Neoarchean, high-grade event that was initiated by the collision of the Kaapvaal and Zimbabwe cratons. However, recent studies (Boshoff et al., 2006; Zeh et al., 2007; Perchuk et al., 2008; Van Reenen et al., 2008; Gerdes and Zeh, 2009; Millonig et al., 2008) have unequivocally demonstrated that parts of the CZ have undergone a series of complex and temporally-discrete events, which include the formation and subsequent anatexis of the Sand River Gneiss at 3.24-3.12 Ga (Zeh et al., 2007; Gerdes and Zeh, 2009), structural, metamorphic and magmatic events at 2.65-2.51 Ga (e.g. Boshoff et al., 2006; Van Reenen et al., 2008; Millonig et al., 2008) and a final $\sim 2.03 \mathrm{Ga}$ metamorphic overprint (e.g. Boshoff et al., 2006; Zeh et al., 2007; Perchuk et al., 2008; Van Reenen et al., 2008; Gerdes and Zeh, 2009).

Despite the fact that the majority of researchers now appear to be reaching a consensus on the temporal evolution of the Limpopo Belt, there are still profound interpretive, tectonic and petrological problems that need addressing. This is exemplified, primarily by conflicting $P-T$ paths. Perchuk et al. (2008) is the only study which proposes from a petrological perspective that they can track the polymetamorphic evolution of single metapelitic sample over $600 \mathrm{Ma}$ of Earth history. The Perchuk et al. (2008) $P-T$ path is characterized by two-stages of decompression cooling (DC) linked via an isobaric heating path (IBH). The first decompression-cooling path (DC1) is interpreted to reflect uplift following a high-grade Neoarchean. The isobaric heating path is interpreted to reflect second high-grade event ca. $2.0 \mathrm{Ga}$, which was immediately followed by a second decompression cooling (DC2) event (Fig. 2). Conversely, Zeh et al. (2004) define a single, clockwise $P-T$ evolution with no petrological evidence of polymetamorphism (Fig. 2). The data presented in this paper, when used in conjunction with that from Zeh et al. (2004) and Perchuk et al. (2008), will highlight and discuss one critical question. Why when using two different methods do rocks of similar composition, from the same field locality, yield markedly different $P-T$ paths?

\section{P-T-t evolution of the Central Zone}

Three temporally distinct structural-metamorphic events are recognized within the $\mathrm{CZ}$ at 3.24-3.12 Ga (D1/M1), 2.58-2.51 Ga (D2/M2) and 2.03 (D3/M3) (Holzer et al., 1998; Kroner et al., 1999; Zeh et al., 2007; Millonig et al., 2008; Gerdes and Zeh, 2009).

The group affected by the M1/D1 event consists primarily of TTG orthogneiss, termed the Sand River Granitoid Suite (which includes the Sand River Gneiss), which is found in relatively small domains across the whole of the $\mathrm{CZ}$ and are interpreted to reflect the remnants of a widespread early Archean terrane (Kröner et al., 1999). A prevalent early Archean magmatic event is further supported by the emplacement of the layered metagabbroic Messina Suite at ca. 3.0 Ga (Barton, 1996). Kroner et al. (1999) relate the M1 event to the first major structural event: D1 - a strong non-coaxial deformation, which produced the first foliation in the SRG together with pervasive gneissose layering and isoclinal folding (Hofmann et al., 1998). The intrusion of the predominantly trondjhemitic gneiss precursors (upstream of the Causeway locality and still part of the Sand River Granitoid Suite) at ca. 3.2 Ga cuts the layering and isoclinal folding in the SRG thus demonstrating that D1 must be older than 3.2 Ga (Kröner et al., 1999). However, based on recent $\mathrm{U}-\mathrm{Pb}$ and $\mathrm{Hf}$ isotope data Zeh et al. (2007) and Gerdes and Zeh (2009) indicate that the SRG was emplaced at ca. 3.28 and underwent discrete anatectic events at 3.14 (M1), 2.61 (M2) and $2.02 \mathrm{Ga}$ (M3).

The D2/M2 event is characterized by the presence of numerous orthogneisses, designated to include the Alldays, Singelele, Zanzibar, Bulai and Zoetfontein Gneisses, which belong to a 27342604 Ma age group (Jaeckel et al., 1997; Kröner et al., 1999; Zeh et al., 2007). Kröner et al. (1999) suggest that the orthogneiss precursors were emplaced into the already ductile and deformed gneisses of the oldest group. The youngest age group within the $\mathrm{D} 2 / \mathrm{M} 2$ event is based solely on one sample - the Tshipise Gneiss, a strongly deformed orthogneiss with a protolith emplacement age of ca. $2510 \mathrm{Ma}$, which has been interpreted to suggest that part of the ductile deformation history of the $\mathrm{CZ}$ occurred in the early Proterozoic (Kröner et al., 1999). Conversely, McCourt and Armstrong (1998) present U-Pb (SHRIMP) data for zircons from synand post-tectonic granites in the western part of the Central Zone.

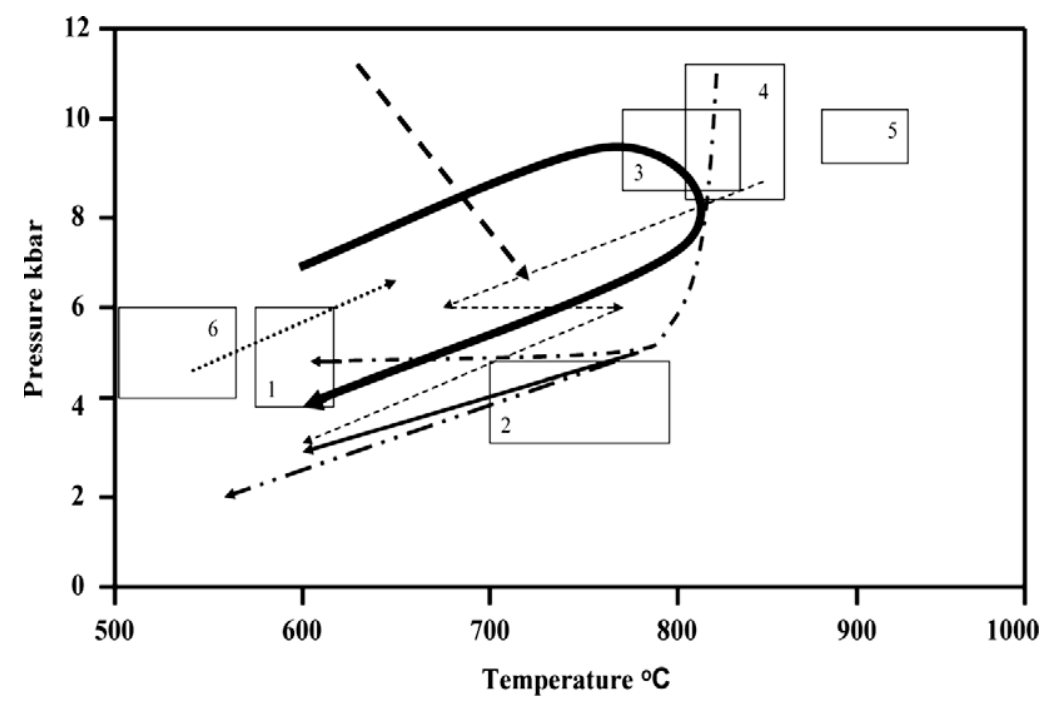

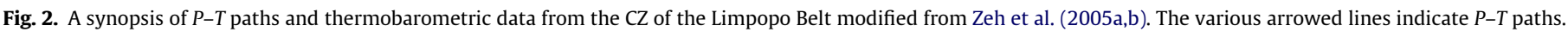

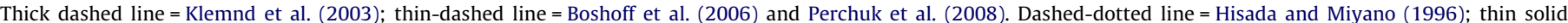

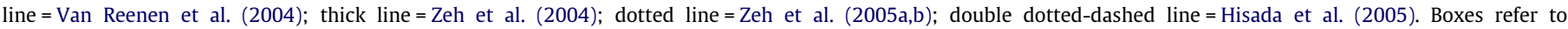
thermobarometric estimates: 1 and 3 = Perchuk et al. (2000), 2 = Harris and Holland (1984); 4 = Droop (1989), 5 and $6=$ Tsunogae and Van Reenen (2006). 
Field and fabric relationships indicate that the syn-tectonic granites dated at ca. $2595+13$ Ma intruded during the Limpopo orogeny, which is interpreted to provide a minimum age constraint for the contractional phase of orogenesis.

Evidence for a second high-grade metamorphic event, M2 (essentially coeval with a D2 non coaxial deformation phase which produced folding and transposition of D1-foliations to produce a second axial plane foliation and a new generation of folding and fabric formation in post-D1 rocks (e.g. SRG sheath folds and type 1 and 2 interference patterns); Hofmann et al., 1998) at ca. 2.62.51 is based on $\mathrm{Pb}$ stepwise leaching dates from sillimanite and cogenetic garnet, obtained from metapelitic xenoliths within the Bulai Pluton (Holzer et al., 1998). Textural relationships indicate that sillimanite + cordierite + garnet are replacing andalusite, which Holzer et al. (1998) interpret to represent a prograde reaction reflecting an anticlockwise low-P/high-T evolution. However, no petrological work on these samples was published.

Field relationships indicate that the Bulai Pluton can be subdivided into an enderbitic intrusive phase at ca. $2.6 \mathrm{Ga}$ and a granitic phase at $2.57 \mathrm{Ga}$ (Barton et al., 1994). The crystallization age of the Bulai granite has recently been refined by Zeh et al. (2007), who determined a precise $\mathrm{U}-\mathrm{Pb}$ zircon age of $2612+/-7$ Ma. Furthermore, Millonig et al. (2008) conducted detailed petrological investigations upon xenoliths within the Bulai granite, providing the first unambiguous evidence of a Neoarchean metamorphic event. $P-T$ pseudosections demonstrate that the metapelitic and charnoenderbitic xenoliths within the Bulai granite underwent a highgrade metamorphic overprint at peak $P-T$ conditions of 830 $860^{\circ} \mathrm{C} / 8-9 \mathrm{kbar}$ followed by a pressure-temperature decrease to $750{ }^{\circ} \mathrm{C} / 5-6$ kbar (Millonig et al., 2008). Coupled with U-Pb analyses of monazite enclosed in garnet from the charno-enderbite gneiss, Millonig et al. (2008) provide robust evidence for a highgrade event at $2644+/-8 \mathrm{Ma}$. Collectively, the data indicates that the metapelitic and charno-enderbitic gneisses underwent uplift, cooling and deformation before they were intruded by the Bulai granite at ca. $2612+/-7 \mathrm{Ma}$ (Zeh et al., 2007). A late Archean high-grade metamorphic event is further supported by Kröner et al. (1999) who present a SHRIMP determined $\mathrm{Pb}^{207} / \mathrm{Pb}^{206}$ age of ca. $2560 \mathrm{Ma}$ for zircons found within melt veins of leucocratic garnetiferous gneiss. This age data therefore constrains the minimum age of anatectic melting and the maximum age of the deformation fabric in the rocks the melt veins intrude. Holzer (1995) described three generations of such rocks, the oldest being intruded by the Bulai and the youngest cutting the Bulai. Coupled with single zircon ages for other granitoid gneisses (Holzer et al., 1998; Kröner et al., 1999; Zeh et al., 2007; Gerdes and Zeh, 2009) it seems the $\mathrm{CZ}$ underwent several pulses of thermal disturbance associated with magmatism and/or tectono-metamorphism between ca 2.7 and $2.5 \mathrm{Ga}$. This magmatic-metamorphic evolution is broadly contemporaneous with than those reported from the NMZ (2.58-2.7 Ga: Berger et al., 1995) and the SMZ (2.662.69 Ga: Kreissig et al., 2001), suggesting a possible causal geodynamic link.

Boshoff et al. (2006), Van Reenen et al. (2008) and Perchuk et al. (2008) advocate the D2/M2 event was a regional, high-grade structural-metamorphic event that was responsible for the development of large-scale sheath folds across the $\mathrm{CZ}$. U-Pb zircon and monazite age data for precursors to leucocratic anatectic gneisses that cut the high-grade gneissic fabric indicate that the major D2/M2 folds developed before $\sim 2.63 \mathrm{Ga}$ (Van Reenen et al., 2008). However, attempts to date D2/M2 metamorphic garnet via the PbSL method yields a large spread of ages ranging from 2.6-2.0 Ga, an artifact which is interpreted to reflect the polymetamorphic history of the CZ (Boshoff et al., 2006; Van Reenen et al., 2008). This interpretation, however, was questioned by Zeh and Klemd (2008).
The timing of the last high-grade metamorphic event (D3/M3) is constrained by the dating of metamorphic minerals (Holzer et al., 1998; Boshoff et al., 2006; Van Reenen et al., 2008; Gerdes and Zeh, 2009), metamorphic overgrowths on igneous or detrital zircons (Barton and Sergeev, 1997; Buick et al., 2006) and igneous zircons from either late-stage granitoids or anatectic sweats (Jaeckel et al. 1997; Kröner et al., 1999; Zeh et al., 2007; Van Reenen et al., 2008). The petrological investigations of Zeh et al. (2004) provide evidence to suggest that pelitic rocks of the BBC underwent a single prograde evolution at ca. $2.0 \mathrm{Ga}$. Using quantitative phase diagrams ( $P-T$ pseudosections) in the system $\mathrm{CaO}-\mathrm{Na}_{2} \mathrm{O}-$ $\mathrm{K}_{2} \mathrm{O}-\mathrm{TiO}_{2}-\mathrm{MnO}-\mathrm{FeO}-\mathrm{MgO}-\mathrm{Al}_{2} \mathrm{O}_{3}-\mathrm{SiO}_{2}-\mathrm{H}_{2} \mathrm{O}$, Zeh et al. (2004) defined a clockwise $P-T$ path that displays a prograde $P-T$ increase from $600{ }^{\circ} \mathrm{C} / 7 \mathrm{kbar}$ to $780^{\circ} \mathrm{C} / 9-10 \mathrm{kbar}$ (pressure peak) and $820^{\circ} \mathrm{C} / 8 \mathrm{kbar}$ (thermal peak), followed by a $P-T$ decrease to $600{ }^{\circ} \mathrm{C} / 4 \mathrm{kbar}$ (Fig. 2). The peak metamorphic $P-T$ conditions agree well with the peak $P-T$ estimates obtained by Droop (1989) and Hisada and Miyano (1996). However, the retrograde path, defined by matrix assemblages, garnet resorption textures, mineral zoning and diffusion patterns (Zeh et al., 2004) requires a simultaneous $P$ $T$ decrease, in agreement with the DC paths defined by Perchuk et al. (2000), Van Reenen et al. (2004), Hisada et al. (2005) and Rigby et al. (2008b) but in stark contrast to retrograde paths defined by ITD (e.g. Droop, 1989; Hisada and Miyano, 1996) and subsequent IBC (Hisada and Miyano, 1996).

Additional evidence for prograde metamorphism during the D3/ M3 event is presented by Zeh et al. (2005a) who calculated a petrogenetic grid in the model system $\mathrm{CaO}-\mathrm{FeO}-\mathrm{MgO}-\mathrm{Al}_{2} \mathrm{O}_{3}-$ $\mathrm{SiO}_{2}-\mathrm{H}_{2} \mathrm{O}$ to derive $\mathrm{P}-\mathrm{T}$ pseudosections that were subsequently employed to infer a contemporaneous $P-T$ increase from $540{ }^{\circ} \mathrm{C}$ 4.5 kbar to $650^{\circ} \mathrm{C} / 6.5 \mathrm{kbar}$ for grunerite-garnet-bearing amphibolites from country rocks surrounding Venetia. This implies that some $\mathrm{CZ}$ rocks never experienced granulite facies metamorphism. Furthermore, this is supported by the $P-T$ pseudosection studies of Zeh et al. (2005b) and Chudy et al. (2009), who unequivocally define a peak of metamorphism that corresponds to Barrovianstyle, amphibolite facies metamorphism with no previous, meltbearing, granulite facies history. The $P-T$ vector defined by Zeh et al. (2005a,b) and Chudy et al. (2009) is similar to that obtained from the metapelitic BBC granulites (Zeh et al., 2004), but is shifted to lower pressures and temperatures. Ultimately, this led Zeh et al. (2005a,b) to conclude that the country rocks surrounding Venetia form the roof zone of the granulite-facies rocks that predominate in the CZ. Moreover, Chudy et al. (2009) have demonstrated that the Barrovian-style metamorphism reported from Venetia formed during the $2.0 \mathrm{Ga}$ event. There was no evidence for Neoarchean metamorphism in the rocks. The zircons analyzed by Chudy et al. (2009) record only a crystallization/detrital Paleoarchean age of 3.34 Ga with a 2.02 metamorphic overgrowth.

A single metamorphic event was further supported by the petrological data obtained by Rigby et al. (2008b) from metasyenites in the West Alldays region. Results from conventional thermobarometry and pseudosection modelling in the chemical system $\mathrm{Na}_{2} \mathrm{O}-\mathrm{CaO}-\mathrm{K}_{2} \mathrm{O}-\mathrm{FeO}-\mathrm{MgO}-\mathrm{Al}_{2} \mathrm{O}_{3}-\mathrm{H}_{2} \mathrm{O}-\mathrm{TiO}_{2}-\mathrm{Fe}_{2} \mathrm{O}_{3}$ indicate the metasyenites underwent a metamorphic evolution that was characterized by a maximum pressure of $8 \mathrm{kbar}$ and temperatures of $\sim 770^{\circ} \mathrm{C}$. Subsequent retrogression involved a simultaneous $P-T$ decrease via decompression-cooling to $4 \mathrm{kbar}$ at temperatures $<550^{\circ} \mathrm{C}$. The inferred $P-T$ path was used in combination with the petrological data of Zeh et al. $(2004,2005)$ to postulate the existence of a metamorphic field gradient (Rigby et al., 2008b).

In contrast, Boshoff et al. (2006) and Van Reenen et al. (2008) interpret field, structural, petrologic and age data to reflect both Archean and Paleoproterozoic granulite-facies tectonometamorphic events. A Paleoproterozoic D3 event shear event is constrained to $2023+/-11 \mathrm{Ma}$ by PbSL of garnet that reflects the 
syntectonic crystallization of garnet-cordierite-sillimanite-biotite-quartz parageneses formed during shearing. The D3 shearing event is superimposed upon earlier D2/M2 structures whose synkinematic minerals yield age dates ranging from ca. 2.6 to ca. $2.0 \mathrm{Ga}$. Boshoff et al. (2006) and Van Reenen et al. (2008) interpret these mixed ages to reflect an earlier, Archean granulite facies event with a later Paleoproterozoic granulite facies overprint. The structural and geochronological data of Boshoff et al. (2006) and Van Reenen et al. (2008) are linked to a 'zig-zag shaped' $P-T$ path defined by Perchuk et al. (2006, 2008) (Fig. 2), which is interpreted to support a polymetamorphic evolution for the $\mathrm{CZ}$. The polymetamorphic $P-T$ path of Perchuk et al. $(2006,2008)$ is characterized by two-stages of decompression-cooling linked via an isobaric heating path. The first decompression-cooling path (DC1), interpreted to reflect the Neoarchean D2/M2 event, descends from 850 to $900{ }^{\circ} \mathrm{C}$ at $8-9$ kbar to $600{ }^{\circ} \mathrm{C}$ at 5-6 kbar. A second ca. $2.0 \mathrm{Ga}$ D3/M3 high-grade event occurred $600 \mathrm{My}$ after DC1, and is characterized by the formation of reaction textures and anatectic sweats during isobaric heating of $\mathrm{D} 2 / \mathrm{M} 2$ gneisses from $600{ }^{\circ} \mathrm{C}$ to $800^{\circ} \mathrm{C}$ at 5-6 kbar. The final stage of the D3/M3 event proceeded at the middle level of the Precambrian crust, and was immediately followed by a second decompression cooling (DC2) event to around $570-600{ }^{\circ} \mathrm{C}$ at $3.5-4.5$ kbar (Perchuk et al., 2008).

In light of the data presented by Zeh et al. (2007), Van Reenen et al. (2008), Gerdes and Zeh (2009) and Millonig et al. (2008) there is a general consenus pertaining to the number and timing of metamorphic events. Collectively the data indicate that at least parts of the $\mathrm{CZ}$ (e.g. Musina) were affected by polymetamorphic evolution. However, pertinent contradictions in the morphology of the Neoproterozoic and Paleoproterozoic $P-T$ paths, prevents at present, the construction of a coherent and inter-related tectonic model (Rigby et al., 2008a).

\section{Petrography}

The sample (RM06-86) investigated forms part of a sequence of exposures at the Verbaard locality within the Sand River, southwest of Messina. The outcrop sampled in this study is composed predominantly of quartzo-feldspathic gneiss that is underlain by a $30-50 \mathrm{~cm}$ thick unit of foliated, migmatitic metapelitic gneiss. The metapelite contains distinct garnet-bearing, foliation-parallel leucosomes measuring up to $2.5 \mathrm{~cm}$ in diameter, which alternate on a $2-3 \mathrm{~cm}$-scale with biotite-rich mesosomes. The proportion of melt in a typical hand-specimen is estimated to range from $25-30 \%$.

Sample RM06-86 is medium-to-coarse grained, stromatic metatexite (Fig. 3A) with the following mineral assemblage: quartz, Kfeldspar, plagioclase, garnet, biotite, rare sillimanite, ilmenite, muscovite, zircon and monazite. The leucosomes have igneous textures, containing large $(\sim 2-3 \mathrm{~mm})$ euhedral-to-subhedral K-feldspars and plagioclase separated by interstitial patches of quartz. Intergrowths of plagioclase and quartz are common forming classic myrmekitic textures. Blocky K-feldspars invariably show fine perthitic exsolution lamellae. Subhedral, poikiloblastic garnets measuring up to $5 \mathrm{~mm}$ occur within the central domains of the leucosome but are generally concentrated along the borders with the mesosomes. Leucosome garnets are dominated by inclusions of quartz along with minor K-feldspar and plagioclase. Retrogression of K-feldspar and plagioclase to fine-grained muscovite/sericite is common throughout the leucosomes. However, retrogression is most intensely developed along the boundaries between the leucosomes and mesosomes, often enclosing and completely replacing the K-feldspar and plagioclase grains that mantle garnet (Fig. 3B).

Biotite occurs in three textural settings: (1) as elongate $1-2 \mathrm{~mm}$ crystals defining the foliation that is separated by patches of
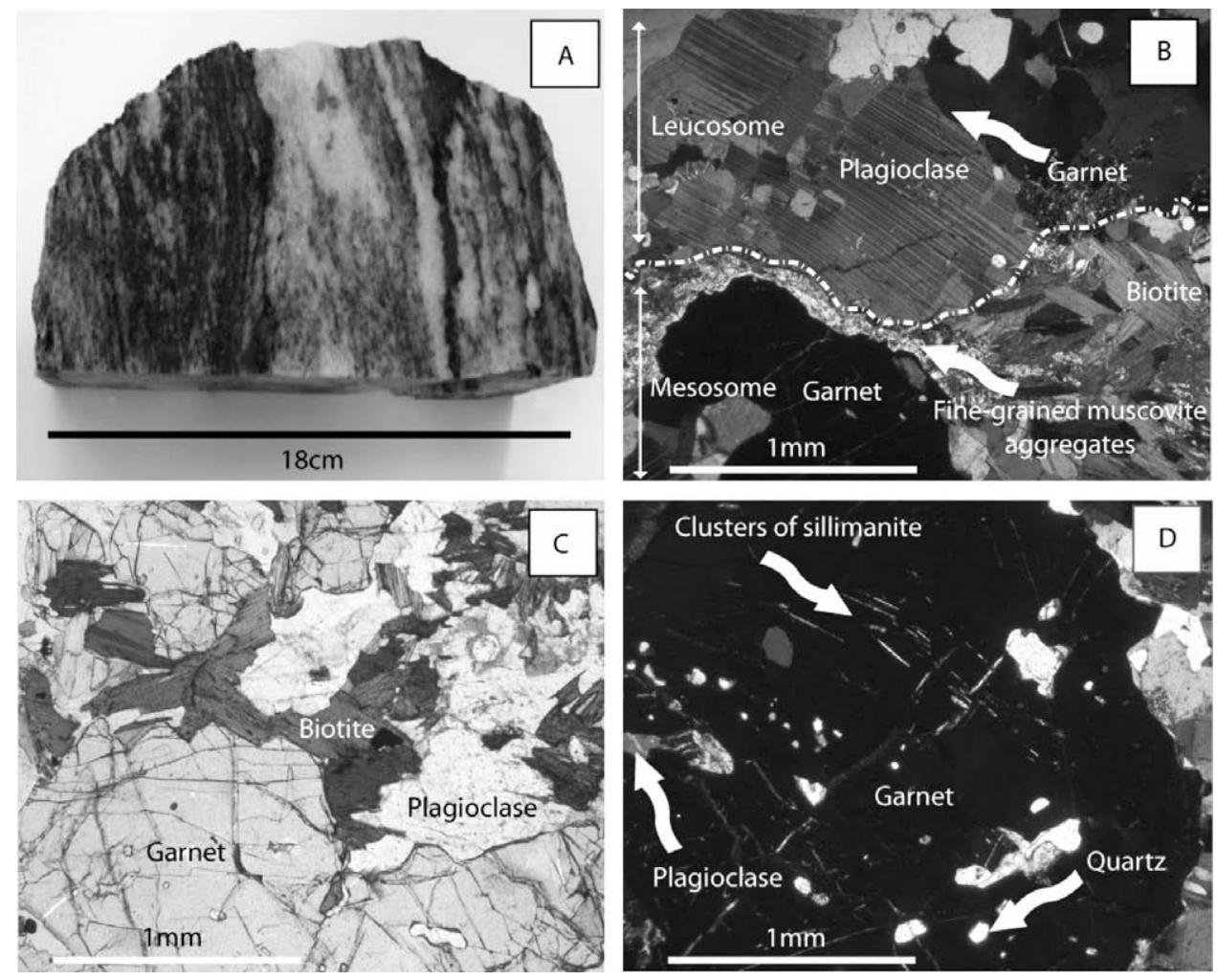

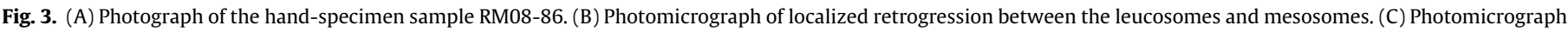
of second generation biotite. (D) Photomicrograph of sillimanite inclusions within garnet from the mesosomes.

Please cite this article in press as: Rigby, M.J. Conflicting P-T paths within the Central Zone of the Limpopo Belt: A consequence of different thermobarometric methods?. J. Afr. Earth Sci. (2009), doi:10.1016/j.jafrearsci.2009.03.005 
granoblastic-polygonal grains of quartz and euhedral K-feldspar and plagioclase, (2) large, randomly oriented $2-3 \mathrm{~mm}$ crystals that mantle and enclose garnet and (3) as small $>0.5 \mathrm{~mm}$ inclusions within garnet. Garnet in the mesosomes measures up to $6 \mathrm{~mm}$ and is invariably resorbed and surrounded by plagioclase and biotite (Fig. 3C). Garnet from the mesosomes contain inclusions of quartz, K-feldspar, plagioclase and rarely sillimanite and biotite (Fig. 3D). Sericitization of K-feldspar and plagioclase is common throughout the mesosomes. The absence of sillimanite in the matrix of the rock implies it was consumed during metamorphism. The peak assemblage is thus interpreted to contain the following: quartz, biotite, garnet, K-feldspar, ilmenite, plagioclase and silicate melt.

\section{Mineral chemistry}

Major element compositions of all minerals were determined by wavelength-dispersive spectrometry (WDS) using a CAMECA SX-100 electron microprobe at the University of Pretoria, with an accelerating voltage of $15 \mathrm{kV}$ and a beam current of $20 \mathrm{nA}$ (Rigby et al., 2008c). A $30 \mu \mathrm{m}$ beam diameter was used for all analyses of K-feldspar in order to obtain a bulk mineral composition that integrates the exsolution lamellae. All other analyses were performed with a beam diameter at $\sim 1 \mu \mathrm{m}$. Concentrations were calculated from relative peak intensities using the internal PAPcorrection software of Pouchou and Pichoir (1991). Representative analyses of the major rock-forming minerals for each sample are presented in Table 1.

Biotites in the metapelitic gneiss can be broadly subdivided into three groups: (1) oriented flakes of biotite that form the foliation in the matrix of the mesosomes and inclusions within matrix quartz and plagioclase, (2) inclusions within garnet, and (3) randomly oriented biotites that mantle and enclose garnet.

Biotites from each group also have a distinctive mineral chemistry (Fig. 4A and B). Group (1) biotites have $\mathrm{XAl}^{\mathrm{VI}}$ contents of between 0.67 and 0.74 . XFe and XTi values ranging from 0.32 to 0.36 and 0.088 to 0.112 , respectively. Group (2) biotites have $X \mathrm{Al}^{\mathrm{VI}}$ contents that range from 0.61 to 0.65 and $X F e$ values ranging from 0.20 to 0.23 . XTi contents are similar to group (1) with values ranging from 0.09 to 0.11 . Group (3) biotites have $X \mathrm{Al}^{\mathrm{VI}}$ contents of between 0.65 and 0.70 . The $X \mathrm{Fe}(\mathrm{Fe} /(\mathrm{Fe}+\mathrm{Mg}))$ values range from 0.25 to 0.30 and $X \mathrm{Ti}(\mathrm{Ti} /(\mathrm{Fe}+\mathrm{Mg}))$ contents range from 0.043 to 0.069 . All biotites in contact with garnet generally have lower XFe values than those distant from garnet, complimenting Fe-enriched garnet rims, and indicating that retrograde $\mathrm{Fe}-\mathrm{Mg}$ exchange has taken place. $\mathrm{Fe}^{3+}$ contents were calculated from the probe analyses using the stoichiometric criteria of Droop (1987). Group (1) biotites have the highest estimated $\mathrm{Fe}^{3+}$ values with ranges from 0.080 to 0.089 (a.p.f.u. [11(0)]), whereas group (2) have the lowest values ranging from 0.049 to 0.061 a.p.f.u.Group (3) biotites preserve contents that range from 0.068 to 0.085 atoms per formula unit (a.p.f.u.)

Zoning profiles across garnets from the mesosomes reveal $X_{\mathrm{Alm}}$ $(\mathrm{Fe} /(\mathrm{Fe}+\mathrm{Mg}+\mathrm{Ca}+\mathrm{Mn}))$ varies from 0.538 in the core to 0.573 at the rims. $X_{\mathrm{Grs}}(\mathrm{Ca} /(\mathrm{Ca}+\mathrm{Fe}+\mathrm{Mg}+\mathrm{Mn}))$ values preserve a relict growth zoning pattern, ranging from 0.058 to 0.062 in the core and rising to a peak of 0.115 before declining to $0.045-0.055$ (Fig. $5 \mathrm{~A}) . X_{\mathrm{Spss}}(\mathrm{Mn} /(\mathrm{Mn}+\mathrm{Fe}+\mathrm{Ca}+\mathrm{Mg}))$ and $X_{\mathrm{And}}\left(\mathrm{Fe}^{3+} /\left(\mathrm{Fe}^{3+}+\mathrm{Al}+\mathrm{Cr}\right)\right.$ show no discernible pattern of variation from cores to rims with very low values ranging from 0.013 to 0.016 and 0.01 to 0.03 , respectively. In order to confirm the observed chemical variation, which is attributed to growth zoning followed by diffusion several, mutually perpendicular traverses across the garnets were ana-

Table 1

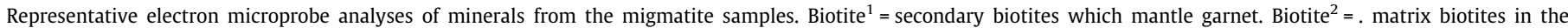
mesosomes. Biotite ${ }^{3}=$ inclusions within garnet. Superscript ${ }^{\mathrm{M}}=$ mesosome Superscript ${ }^{\mathrm{INT}}$ indicates intermediate zone between core and rim.

\begin{tabular}{|c|c|c|c|c|c|c|c|c|c|c|c|}
\hline & Biotite $^{1}$ & Biotite $^{2}$ & Biotite $^{3}$ & $\mathrm{Grt}^{\mathrm{RIM}}$ & $\mathrm{Grt}^{\mathrm{INT}}$ & $\mathrm{Grt}^{\mathrm{CORE}}$ & $\mathrm{Pl}^{\mathrm{RIM}}$ & $\mathrm{Pl}^{\mathrm{INT}}$ & $\mathrm{Pl}^{\mathrm{CORE}}$ & Ms & $\mathrm{Ksp}^{\mathrm{M}}$ \\
\hline $\mathrm{SiO}_{2}$ & 36.70 & 36.91 & 38.13 & 39.09 & 38.94 & 39.06 & 56.36 & 55.64 & 56.19 & 51.23 & 64.18 \\
\hline $\mathrm{TiO}_{2}$ & 2.30 & 3.66 & 3.98 & 0.01 & 0.04 & 0.00 & 0.01 & 0.01 & 0.04 & 0.01 & 0.01 \\
\hline $\mathrm{Al}_{2} \mathrm{O}_{3}$ & 19.02 & 18.31 & 17.76 & 21.70 & 22.48 & 21.72 & 27.94 & 28.38 & 27.82 & 28.78 & 18.93 \\
\hline $\mathrm{Cr}_{2} \mathrm{O}_{3}$ & 0.17 & 0.17 & 0.24 & 0.09 & 0.05 & 0.08 & 0.02 & 0.02 & 0.01 & 0.00 & 0.00 \\
\hline $\mathrm{Fe}_{2} \mathrm{O}_{3}$ & 1.36 & 1.59 & 1.14 & 0.42 & 0.29 & 0.31 & 0.00 & 0.00 & 0.00 & 0.00 & \\
\hline $\mathrm{FeO}$ & 11.03 & 12.89 & 9.27 & 25.66 & 25.11 & 25.50 & 0.00 & 0.03 & 0.04 & 1.54 & 0.09 \\
\hline $\mathrm{MnO}$ & 0.03 & 0.06 & 0.05 & 0.66 & 0.67 & 0.64 & 0.00 & 0.00 & 0.02 & 0.00 & 0.06 \\
\hline MgO & 16.42 & 13.52 & 17.73 & 9.97 & 8.65 & 9.85 & 0.00 & 0.01 & 0.00 & 2.67 & 0.02 \\
\hline $\mathrm{CaO}$ & 0.05 & 0.01 & 0.01 & 2.07 & 4.21 & 2.34 & 9.41 & 10.06 & 9.27 & 0.02 & 0.10 \\
\hline $\mathrm{Na}_{2} \mathrm{O}$ & 0.15 & 0.13 & 0.35 & n.a. & n.a. & n.a. & 5.98 & 5.65 & 6.08 & 0.04 & 1.24 \\
\hline $\mathrm{K}_{2} \mathrm{O}$ & 8.05 & 9.43 & 8.97 & n.a. & n.a. & n.a. & 0.27 & 0.31 & 0.27 & 10.48 & 14.74 \\
\hline Total & 95.29 & 96.68 & 97.63 & 99.67 & 99.67 & 99.99 & 99.99 & 100.11 & 99.73 & 94.77 & 99.37 \\
\hline Formula & $11(0)$ & $11(0)$ & $11(0)$ & $12(0)$ & $12(0)$ & $8(0)$ & $8(0)$ & $8(0)$ & $8(0)$ & $11(0)$ & $8(0)$ \\
\hline $\mathrm{Si}$ & 2.668 & 2.692 & 2.697 & 3.002 & 2.976 & 3.004 & 2.530 & 2.501 & 2.530 & 3.408 & 2.973 \\
\hline $\mathrm{Ti}$ & 0.126 & 0.201 & 0.212 & 0.00 & 0.002 & 0.000 & 0.000 & 0.000 & 0.001 & 0.001 & 0.000 \\
\hline $\mathrm{Al}$ & 1.630 & 1.574 & 1.480 & 1.96 & 2.025 & 1.969 & 1.478 & 1.503 & 1.476 & 2.256 & 1.033 \\
\hline $\mathrm{Cr}$ & 0.010 & 0.010 & 0.013 & 0.00 & 0.003 & 0.005 & 0.001 & 0.001 & 0.000 & 0.000 & 0.000 \\
\hline $\mathrm{Fe}^{3+}$ & 0.075 & 0.087 & 0.061 & 0.03 & 0.017 & 0.018 & 0.000 & 0.001 & 0.002 & 0.000 & \\
\hline $\mathrm{Fe}^{2+}$ & 0.671 & 0.786 & 0.548 & 1.65 & 1.604 & 1.640 & 0.000 & 0.000 & 0.001 & 0.086 & 0.003 \\
\hline $\mathrm{Mn}$ & 0.002 & 0.004 & 0.003 & 0.04 & 0.043 & 0.042 & 0.000 & 0.001 & 0.000 & 0.000 & 0.002 \\
\hline $\mathrm{Mg}$ & 1.780 & 1.470 & 1.870 & 1.14 & 0.985 & 1.129 & 0.000 & 0.000 & 0.000 & 0.265 & 0.001 \\
\hline $\mathrm{Ca}$ & 0.004 & 0.001 & 0.001 & 0.17 & 0.345 & 0.193 & 0.453 & 0.484 & 0.447 & 0.001 & 0.005 \\
\hline $\mathrm{Na}$ & 0.021 & 0.018 & 0.048 & n.a. & n.a. & n.a. & 0.520 & 0.492 & 0.531 & 0.005 & 0.111 \\
\hline $\mathrm{K}$ & 0.747 & 0.877 & 0.809 & n.a. & n.a. & n.a. & 0.015 & 0.018 & 0.016 & 0.889 & 0.871 \\
\hline Total & 7.733 & 7.720 & 7.743 & 8.00 & 8.00 & 8.00 & 5.00 & 5.00 & 5.00 & 6.911 & 5.001 \\
\hline XFe & 0.274 & 0.348 & 0.227 & 0.591 & 0.620 & 0.592 & & & & 0.244 & \\
\hline$X_{\mathrm{Alm}}$ & & & & 0.549 & 0.539 & 0.546 & & & & & \\
\hline$X_{\text {Spss }}$ & & & & 0.014 & 0.015 & 0.014 & & & & & \\
\hline$X_{\mathrm{Py}}$ & & & & 0.380 & 0.331 & 0.376 & & & & & \\
\hline$X_{\mathrm{Grs}}$ & & & & 0.057 & 0.116 & 0.064 & & & & & \\
\hline$X_{\text {And }}$ & & & & 0.012 & 0.008 & 0.009 & & & & & \\
\hline$X_{\text {Or }}$ & & & & & & & 0.016 & 0.018 & 0.016 & & 0.882 \\
\hline$X_{\text {An }}$ & & & & & & & 0.458 & 0.487 & 0.457 & & 0.005 \\
\hline
\end{tabular}



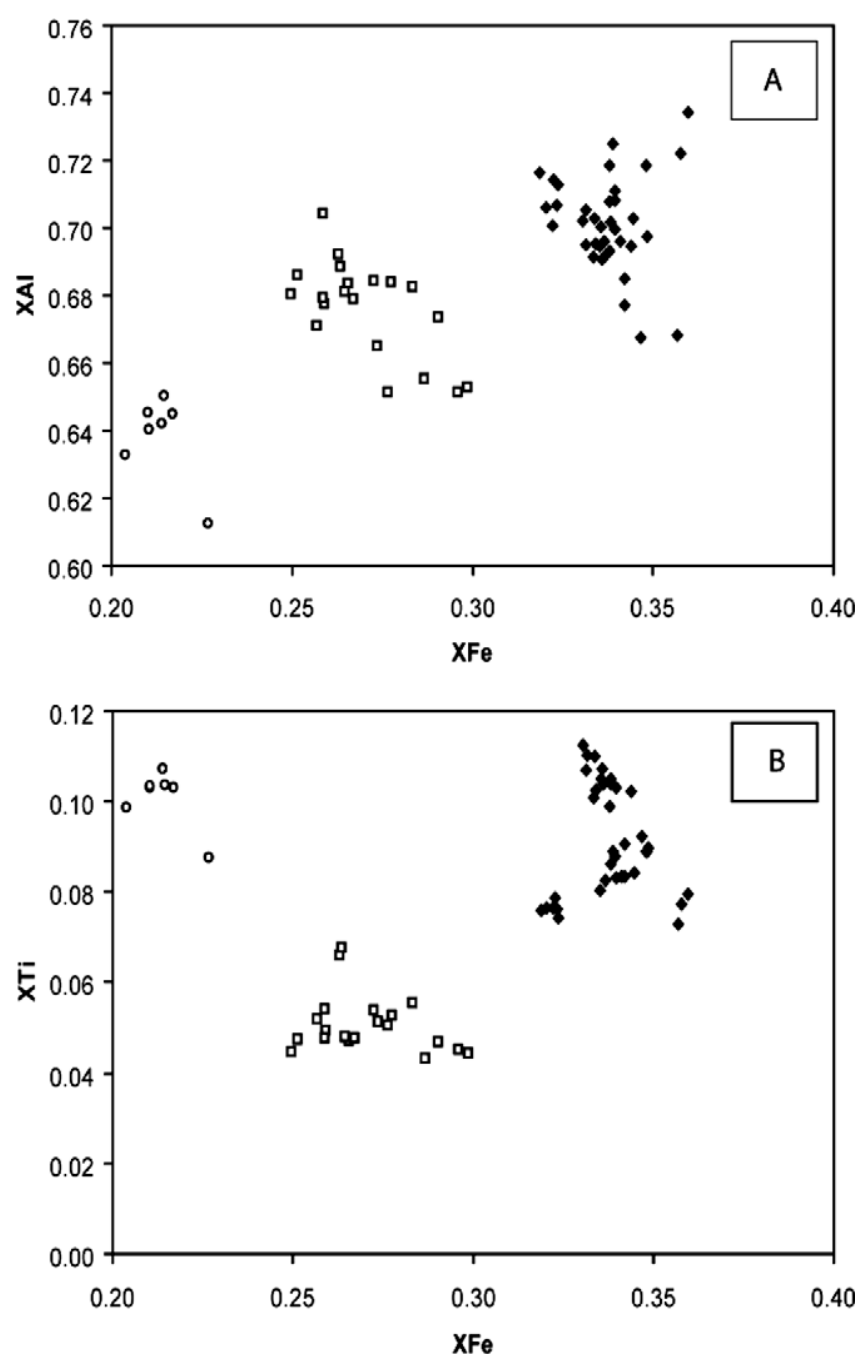

Fig. 4. Biotite compositions. (A) XAl versus XFe. (B) XTi versus XFe. Note there are three distinct populations. lyzed. . Irrespective of the orientation all traverses record a similar pattern of zonation to that depicted in Fig. 5A, thus confirming a typical, concentric-style of growth zonation that was followed by retrograde diffusion along the rims.

Secondary white micas range in composition between the muscovite and phengite end-members with 6.5-7 Si and 0.183-0.283 $\mathrm{Fe}+\mathrm{Mg}$ per 22(O), and the A sites are predominantly potassium rich with $X K(K /(K+N a+\mathrm{Ca})$ values ranging from 0.810 to 0.889 . K-feldspars in the leucosomes and mesosomes have integrated compositions of $\mathrm{Or}_{85-88}$ and $\mathrm{Or}_{91-93}$, respectively. The K-feldspars in the leucosomes are more $\mathrm{Na}$-rich with compositions of $\mathrm{Ab}_{11-14}$ whereas those in the mesosomes are $A b_{7-8}$. Zoning profiles across plagioclase grains from the mesosomes reveal $X_{\mathrm{An}}(\mathrm{Ca} /(\mathrm{Ca}+\mathrm{Na})$ values of $\sim 0.42-$ 0.45 in the cores of plagioclase grains increase steadily rim-wards to $X_{\text {An }}$ values of $=0.49-0.52$ and then decrease again to $X_{\text {An }}$ values of $0.42-0.47$ (Fig. 4B). Plagioclase in the leucosomes have core values of $X_{\mathrm{An}}=0.47-0.48$ and rim values of $0.41-0.44$.

\section{Mineral equilibria modelling}

\subsection{Bulk-composition and rationale}

In order to constrain the $P-T$ history of sample RM06-86 a pseudosection was calculated via the method of Powell et al. (1998) using the software THERMOCALC v.3.26 (Powell and Holland, 1988 and recent upgrades) and the internally-consistent dataset of Holland and Powell (1998). In order to gain additional constraints on the $P-T$ evolution of the mineral assemblages the pseudosection (Fig. 6A) is contoured with the modes of garnet, biotite, plagioclase, sillimanite, quartz and silicate melt (Fig. 6B). Furthermore compositional isopleths for biotite, $X_{\mathrm{An}}(\mathrm{Ca} / \mathrm{Ca}+\mathrm{Na})$ in plagioclase and $X_{\mathrm{Grs}}(\mathrm{Ca} / \mathrm{Ca}+\mathrm{Fe}+\mathrm{Mg}+\mathrm{Mn})$ for garnet are provided (Fig. 5C and D). The mineral equilibria modelling were performed in the model chemical system $\mathrm{MnO}-\mathrm{Na}_{2} \mathrm{O}-\mathrm{CaO}-\mathrm{K}_{2} \mathrm{O}-\mathrm{FeO}-\mathrm{MgO}-$ $\mathrm{Al}_{2} \mathrm{O}_{3}-\mathrm{H}_{2} \mathrm{O}-\mathrm{TiO}_{2}-\mathrm{Fe}_{2} \mathrm{O}_{3}$ (MnNCKFMASHTO). This model chemical system takes account of all the major element components in the phases present in the sample investigated in this study. The activity-composition relations for each of the minerals in the model chemical system are the same as those used by White et al.
(A) Metapelite RM06-86: zoning profile in garnet

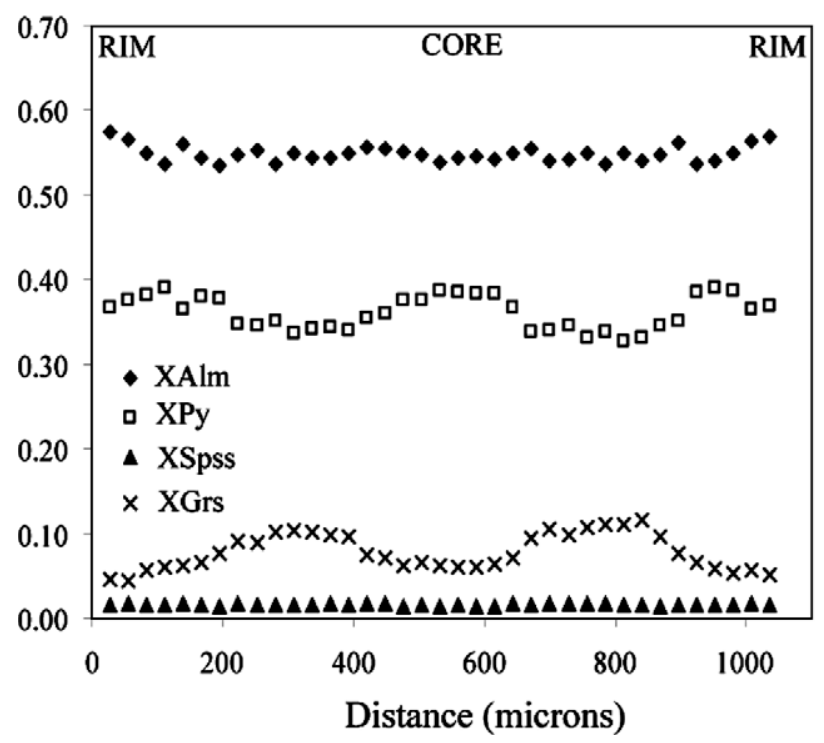

(B) Metapelite RM06-86: zoning profile in plagioclase

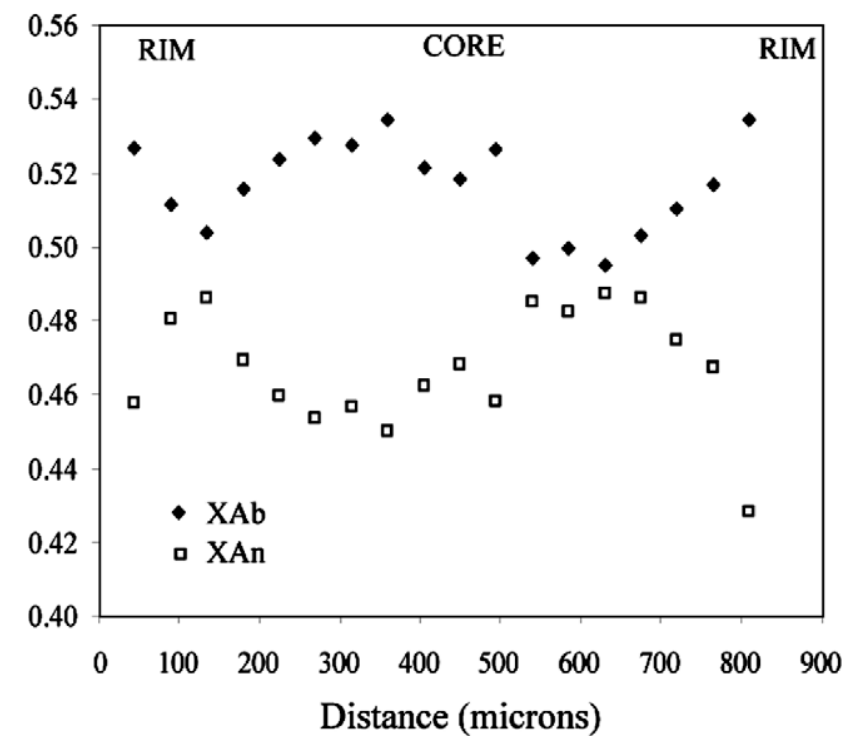

Fig. 5. Zoning profiles in (A) garnet from the mesosomes, and (B) plagioclase from the mesosomes. 

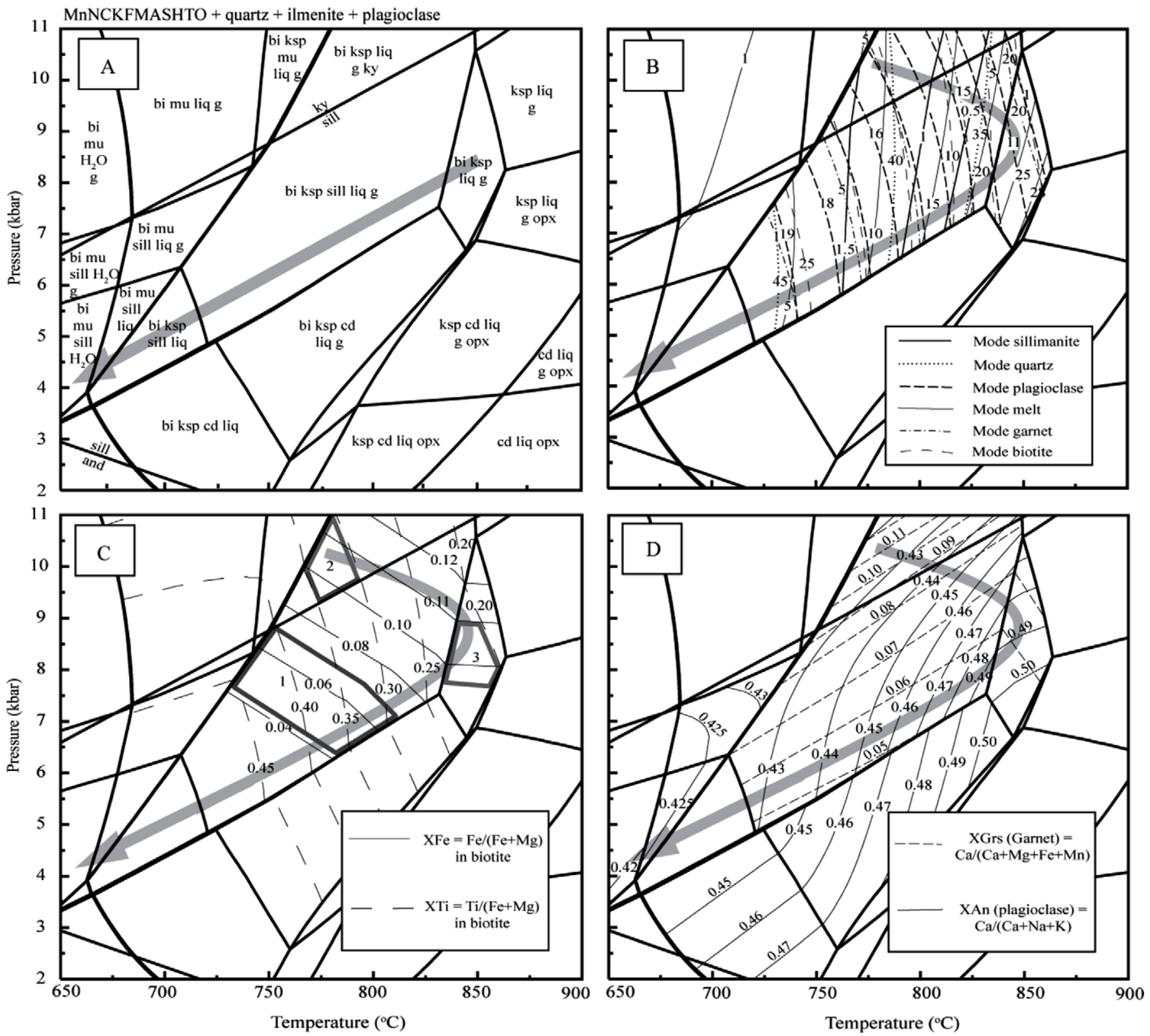

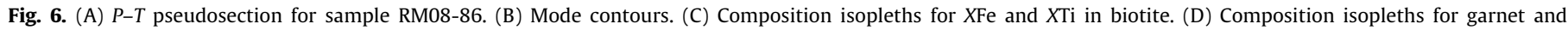
plagioclase.

(2005). The following abbreviations will be used for the phases present in the various fields of the pseudosections: quartz (q), plagioclase ( $\mathrm{pl}$ ), K-feldspar (ksp), garnet ( $\mathrm{g}$ ), biotite (bi), muscovite (mu), ilmenite (ilm), sillimanite (sill), kyanite (ky), cordierite (cd), orthopyroxene (opx), silicate melt (liq), water $\left(\mathrm{H}_{2} \mathrm{O}\right)$.

Whole-rock major elements (Table 2) were analyzed by XRF in order to constrain the bulk-rock compositions to be used in the mineral equilibria modelling. Whole-rock $\mathrm{Fe}^{3+}$ contents were estimated using the modal proportions of $\mathrm{Fe}^{3+}$ bearing minerals. The $\mathrm{Fe}^{3+}$ content of $\mathrm{Fe}$ bearing minerals was calculated from EPMA analyses using the stoichiometric criteria of Droop (1987). The $\mathrm{H}_{2} \mathrm{O}$ content of the bulk-rock composition was fixed so that the assemblages immediately below the solidus are saturated with respect to $\mathrm{H}_{2} \mathrm{O}$ over the entire pressure range. The potential effects of varying $\mathrm{H}_{2} \mathrm{O}$ are discussed later. The sample analyzed via XRF was selected on the basis that is contained the average observed melt proportion, effectively representing the migmatite in outcrop. Whilst this approach has been commonly adopted (e.g. Zeh et al.,
2004; Harris et al., 2004), it is not without flaws. High-grade rocks that have undergone partial melting inevitably loose a certain proportion of melt (White and Powell, 2002). The loss of melt from the system effectively alters the bulk-composition of the rock, which in turn will alter the $P-T-X$ range of phase stability fields within the pseudosection (White et al., 2004). A melt re-integrated composition would be required for an accurate assessment of the prograde conditions during metamorphism. However, the focus of this present study and the conflict between published $P-T$ paths pertains to the post-high-pressure history of the rocks. A bulk-composition from a representative sample contains melt which had remained in the system after potential melt loss. Therefore a measured bulk composition is an adequate representation for assessing peak-toretrograde conditions, assuming melt loss occurred at or near to the peak of metamorphism. The assumptions, strengths and weaknesses of the pseudosection approach to thermobarometry are discussed in detail later, highlighting that the selection of an adequate bulk-composition is crucial to obtaining reliable results. 
Table 2

XRF data expressed as mol.\% and normalized to 100 for input into to THERMOCALC.

\begin{tabular}{lc}
\hline Oxide & RMO6-86 (mol.\%) \\
\hline $\mathrm{SiO}_{2}$ & 71.50 \\
$\mathrm{TiO}_{2}$ & 0.41 \\
$\mathrm{Al}_{2} \mathrm{O}_{3}$ & 8.15 \\
$\mathrm{FeO} \mathrm{Fe}_{2} \mathrm{O}_{3}{ }^{\mathrm{b}}$ & 4.75 \\
$\mathrm{MnO}$ & 0.24 \\
$\mathrm{MgO}$ & 0.08 \\
$\mathrm{CaO}$ & 4.57 \\
$\mathrm{Na}_{2} \mathrm{O}$ & 2.13 \\
$\mathrm{~K}_{2} \mathrm{O}$ & 1.44 \\
$\mathrm{H}_{2} \mathrm{O}^{\mathrm{a}}$ & 2.13 \\
Normalized total & 4.58 \\
\end{tabular}

${ }^{\text {a }}$ Loss on ignition values for $\mathrm{H}_{2} \mathrm{O}$ were omitted in order to fix the $\mathrm{H}_{2} \mathrm{O}$ content of each rock, enabling the solidus to be saturated over the pressure range of the pseudosection(s).

b $\mathrm{Fe}_{2} \mathrm{O}_{3}$ contents were estimated from the modal proportions of $\mathrm{Fe}^{3+}$ bearing minerals. The $\mathrm{Fe}^{3+}$ contents of minerals were determined from probe analyses using the stoichiometric criteria of Droop (1987).

\subsection{Results}

The petrographic, textural and mineral chemical data collectively constrain the subsequent development of the following mineral assemblages: The early/prograde assemblage consisted of quartz + plagioclase I + group I biotite + sillimanite + ilmenite + garnet (both growth zoned garnet in the mesosomes and peritectic garnet in leucosomes) $+\mathrm{K}$-feldspar $+/-$ liquid. The peak assemblage consists of quartz + plagioclase II + group II biotites + ilmenite + garnet (both growth zoned garnet in the mesosomes and peritectic garnet in leucosomes) $+\mathrm{K}$-feldspar + liquid. The observed retrograde assemblage(s) consist of quartz + plagioclase III + group III biotite + ilmenite +/ $\mathrm{K}$-feldspar + muscovite $+\mathrm{H}_{2} \mathrm{O}$. The $P-T$ pseudosection constrains the observed peak assemblage (biotite, K-feldspar, garnet, liquid, quartz, plagioclase and ilmenite) to a narrow temperature range $\sim 830-860^{\circ} \mathrm{C}$, which is inferred to represent the thermal peak of the $P-T$ path. The peak assemblage differs from the early prograde assemblage due to the absence of sillimanite. It is likely that sillimanite was consumed by the following reaction biotite + Al-silicate + plagioclase $+\mathrm{qtz}=$ garnet + K-feldspar + melt (Le Breton and Thompson, 1988) prior to the development of the peak assemblage. The operation of this reaction is also supported by modelling, which demonstrates as temperature increases the modes of biotite, sillimanite, quartz and plagioclase all decrease whilst the modes of garnet, K-feldspar and melt increase.

The pressure range of the peak-temperature mineral assemblage is quiet wide, extending from 6.5 to 10.5 kbar. However, a minimum pressure estimate of $\sim 7.5 \mathrm{kbar}$ is constrained by the adjacent cordierite-in fields. Any subsequent retrogression at pressures below this value, along either a decompression cooling or a near-isothermal decompression path will result in the formation of cordierite, a mineral whose presence was not observed in the sample. The observed retrograde mineral assemblage differs slightly from the modelled retrograde assemblage owing to the absence of a small amount $(<0.5 \%)$ of sillimanite. Sillimanite was observed only as rare inclusions within garnet which are effectively closed from other potential reactants during subsequent heating and retrogression. I therefore infer that the sillimanite inclusions represent part of an early prograde assemblage possibly before the growth of garnet. Alternatively, the small amount of sillimanite predicted by the pseudosection may have been consumed during prograde heating just prior to the formation of the peak-temperature/observed mineral assemblage, a field, which is bound by the sillimanite-out line. If prograde sillimanite was consumed by the formation of melt, then the formation of second generation sillimanite during retrogressive cooling, as a result of back reaction from the melt, will be unlikely as this reaction thermodynamically inhibited.

Prior to retrogression all available free- $\mathrm{H}_{2} \mathrm{O}$ will be partitioned into the melt (Powell, 1983; Stevens and Clemens, 1993; Clemens and Droop, 1998; Johannes and Holtz, 1996; Harley and Carrington, 2001; Rigby et al., 2008d), only when the melt crystallizes and expels $\mathrm{H}_{2} \mathrm{O}$ as free-fluid phase will subsequent retrogression of the peak-metamorphic assemblage take place (Stevens, 1997; White and Powell, 2002). The formation of muscovite adjacent to the leucosomes and the wide-spread retrogression of $\mathrm{K}$-feldspar indicate that $\mathrm{H}_{2} \mathrm{O}$ was released from the melt, which in turn fuelled the retrogression. The modelled retrograde assemblage (biotite, muscovite, $\mathrm{H}_{2} \mathrm{O}$, quartz, ilmenite and plagioclase) lies below the solidus $\left(>675^{\circ} \mathrm{C}\right)$ at pressures of 4-6 kbar. Along the proposed retrograde path the mode of garnet decreases whilst the modes of biotite and plagioclase increase, which is consistent with the observed garnet resorption textures and the mantles of second generation biotite and plagioclase adjacent to garnet.

In addition to comparing the observed/inferred assemblages to their respective fields on the phase diagram, constraints on a $P-T$ path can be obtained from comparing modelled mineral chemistry variations to those that have been measured. Early prograde $P-T$ conditions may be inferred from garnets in the mesosomes that preserve a relict growth zoning. $X_{\text {Grs }}$ contents yield values of $\sim 0.06$ in the cores of garnets that then increase rimwards to $X_{\mathrm{Grs}}$ values of 0.11 . This increase is indicative of prograde growth associated with increasing pressure and temperature. The $X_{\mathrm{Grs}}$ content then steadily decreases to around 0.05 . This M-shaped zoning profile is consistent with changes in the modelled $X_{\mathrm{Grs}}$ isopleths along the proposed $P-T$ path (Fig. 6D). Prograde $P-T$ conditions are also inferred from the zoning profiles obtained from plagioclase (Fig. 5B), where XCa values of $\sim 0.42$ in the cores of plagioclase grains increase steadily rim-wards to $X C$ a values of $=0.49-0.50$ and then decrease again to XCa values of $0.42-0.43$. Inspection of the pseudosection (Fig. $6 \mathrm{D}$ ) reveals this zoning profile is consistent with changes in the modelled $X C$ a isopleths along the proposed $P-T$ path.

Biotite forms in three distinct textural settings, each of which has a unique composition (Fig. 4). Modelled XFe and XTi isopleths (Fig. 6C) demonstrate that each of these measured compositions is stable over different $P-T$ ranges. Group 1 biotites have measured $X F$ and $X$ Ti values that are compatible with the modelled isopleths at 9-11 kbar and $\sim 775-800^{\circ} \mathrm{C}$. The compatibility is reliable as the group 1 biotites are distant from garnet and therefore are unlikely to have been affected by retrograde Fe-Mg diffusion. Group 2 biotites have measured that XFe and XTi that compatible with modelled $X F$ and $X \mathrm{Ti}$ isopleths over the $P-T$ range 7.5-9 kbar and $830-860^{\circ} \mathrm{C}$. The $X \mathrm{Ti}$ values are the same as those determined for group 1 biotites but the XFe values differ. Group 2 biotites probably had similar starting compositions to those in group 1 but the XFe values changed due to cation exchange with the enclosing garnet. Group 3 biotites (those which mantle and enclose garnet) have measured XTi ranges that are compatible with the modelled XTi isopleths from 6 to $8.5 \mathrm{kbar}$ and $725-825^{\circ} \mathrm{C}$. For this XTi range group 3 biotites should have $X F$ values in the range $0.3-0.45$ (as determined from the modelled isopleths), however the measured contents are slightly lower $(0.25-0.30)$. This disparity may be satisfactorily explained by only partial retrograde $\mathrm{Fe}-\mathrm{Mg}$ exchange with the adjacent garnets. In general, the coupling between the biotites textural setting and the agreement between the measured and modelled XFe and XTi isopleths further supports the $P-T$ path delineated in Fig. 6. 


\section{Discussion}

\subsection{P-T path}

The preserved growth zoning in garnet and the biotite compositions provide evidence of an early prograde $P-T$ history, which is characterized by a high pressure phase at $10.5+/-0.5 \mathrm{kbar}$ at $805+/-10^{\circ} \mathrm{C}$, followed by a simultaneous pressure decrease and temperature increase to $8-9 \mathrm{kbar}$ and $840+/-10^{\circ} \mathrm{C}$. However, the bulk-composition selected for pseudosection modelling is only appropriate for investigating peak-to-retrograde conditions, as potential melt loss at, or near to the thermal peak of metamorphism has not been taken into account (c.f. White and Powell, 2002; White et al, 2004). Therefore the prograde path, in terms of an exact $P-T$ trajectory should be regarded with caution. However, it should be noted that the relict growth zoning in garnet is robust evidence of an early prograde history, even if the path has not been adequately modelled in $P-T$ space, at present. However, the results of the $P-T$ pseudosections and isopleth modelling (Fig. 6A-D) are consistent with the modes, compositions and zonations in the observed mineral assemblages, which define a $P-T$ path that traverses from peak conditions of $8-9 \mathrm{kbar}$ and $840+/-10^{\circ} \mathrm{C}$ along a decompression cooling path to $4.5-5.5 \mathrm{kbar}$ and $\sim 650^{\circ} \mathrm{C}$. The peak $P-T$ conditions from this study are in agreement with those determined by Watkeys et al. (1983), Windley et al. (1984), Droop (1989), Hisada and Miyano (1996) and Perchuk et al. (2000). The retrograde path, characterized by decompression cooling, is in agreement with the paths defined by Zeh et al. (2004), Van Reenen et al. (2004), and Boshoff et al. (2006) and the DC1 path of Perchuk et al. (2008). The path is, however, inconsistent with isothermal decompression (Droop, 1989) followed by isobaric cooling (Hisada and Miyano, 1996). Retrograde paths characterized by ITD (Droop, 1989) have been used as evidence to support a 'pop-up' style of exhumation for the CZ (e.g. Roering et al., 1992; Holzer et al., 1998). However, in light of the DC path obtained from this study we support the conclusion of Zeh et al. (2004) that exhumation was controlled, predominantly, by erosion.

In general, the $P-T$ path defined in this study is in excellent agreement with the $P-T$ path defined by Zeh et al. (2004) who em- ployed pseudosection analysis to determine a clockwise evolution displaying a prograde $P-T$ increase from $600^{\circ} \mathrm{C} / 7 \mathrm{kbar}$ to $780^{\circ} \mathrm{C} / 9$ $10 \mathrm{kbar}$ (pressure peak) and $820^{\circ} \mathrm{C} / 8 \mathrm{kbar}$, which was followed by a $P$-T decrease to $600^{\circ} \mathrm{C} / 4$ kbar. There are, however, slight differences. The observed peak assemblage in this study, which corresponds to the thermal peak of metamorphism is tightly constrained to a very narrow field with a temperature range of $830-860^{\circ} \mathrm{C}$; results that are slightly higher than the $820^{\circ} \mathrm{C}$ reported by Zeh et al. (2004) but within error of one another. The excellent agreement between the studies, which used rocks of different composition, from different localities to determine essentially the same results, indicates that the $P-T$ path(s) determined are consistent and reliable. This emphasizes the power of pseudosection analysis in order to accurately constrain the $P-T$ evolution of mineral assemblages and strongly supports the notion that some of the contradictory $P-T$ estimates and $P-T$ paths derived for parts of the $\mathrm{CZ}$ may be erroneous.

\subsection{Conflicting $P-T$ paths}

The congruity of $P-T$ paths and $P-T$ estimates from the aforementioned studies suggests that most workers agree upon the character and style of at least one metamorphic event, which is characterized by an early high-pressure phase, subsequent heating to granulite facies conditions and decompression-cooling during uplift. However, the single clockwise evolution of Zeh et al. (2004), which is supported by the data presented in this study, strongly refutes the twofold metamorphic evolution proposed by Perchuk et al. (2008). The first decompression-cooling path (DC1) of Perchuk et al. (2008) descends from $850-900{ }^{\circ} \mathrm{C}$ at $8-9$ kbar to $600{ }^{\circ} \mathrm{C}$ at 5-6 kbar, which conforms to the results from this study and Zeh et al. (2004). However, the second high-grade event proposed by Perchuk et al. (2008) involves isobaric heating from $\sim 600^{\circ} \mathrm{C}$ to $\sim 800^{\circ} \mathrm{C}$ at $5-6 \mathrm{kbar}$. The effects of such an event should be evident in the petrological record. The isobaric heating path of Perchuk et al. (2008) has been superimposed onto the pseudosection calculated in this study (Fig. 7A) and the pseudosection calculated for sample KA by Zeh et al. (2004) (Fig. 7B). Examination of Fig. 7A reveals that if sample RM06-86 had been subjected isobaric
MnNCKFMASHTO + quartz + ilmenite + plagioclase

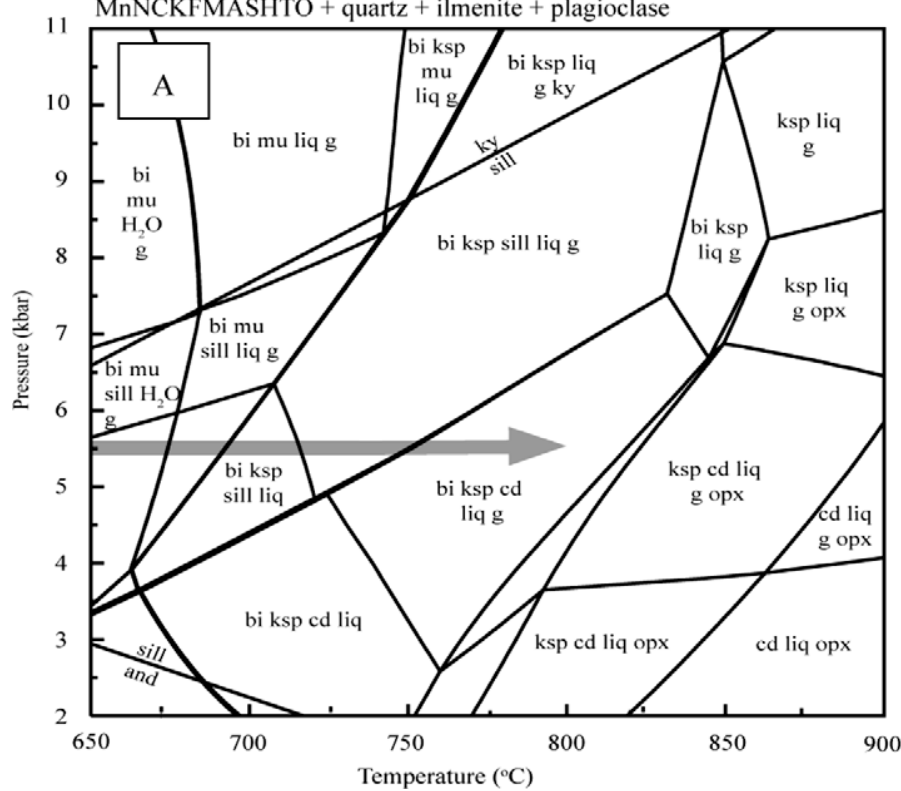

MnNCKFMASH + quartz + plagioclase

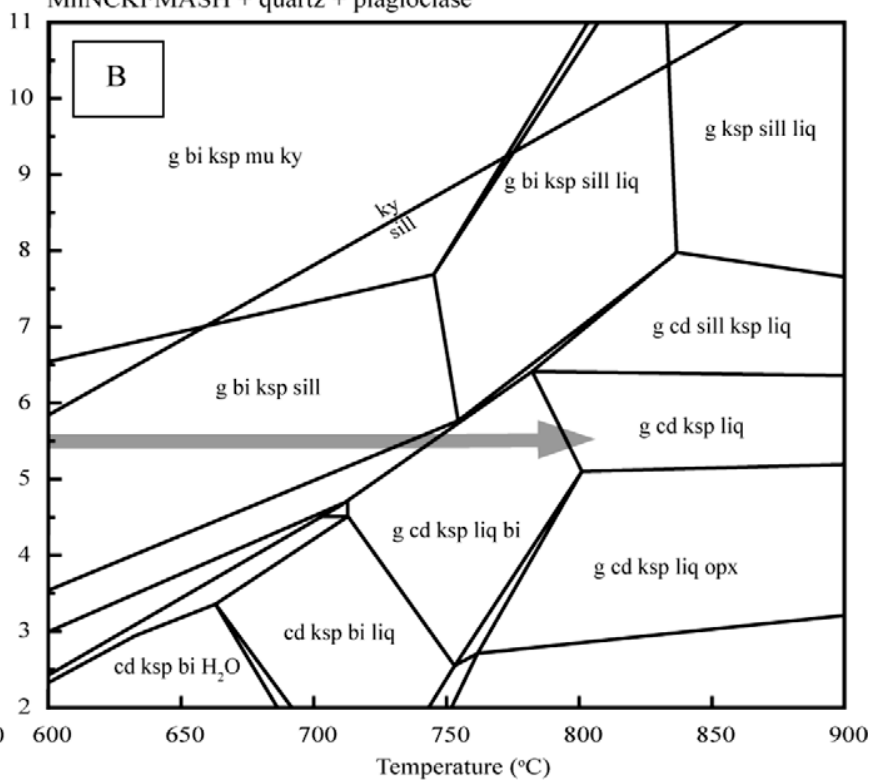

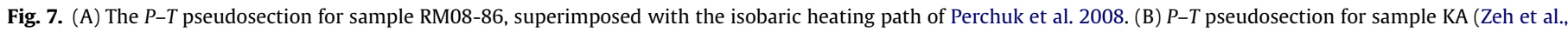
2004) superimposed with the isobaric heating path of Perchuk et al. (2008). 
heating then this would result in the formation of cordierite. Cordierite was not observed in the sample, nor was any reaction texture that could have potentially replaced cordierite upon further retrogression. Similarly, by superimposing the isobaric heating path onto Fig. 7B, sample KA would loose both sillimanite and biotite, minerals that are present in the sample. In short, if the isobaric heating event did occur, then it would lead to the development of completely different mineral assemblages, which are not observed in the rock. Furthermore, an isobaric heating event would change the observed modes, zoning and compositions of the minerals in the assemblage. If such a change had occurred, then the measured and modelled data would not be consistent with the $P-T$ path delineated in this study and that of Zeh et al. (2004). The data can only define a single clockwise $P-T$ path that does not involve the proposed isobaric heating event. Perchuk et al. (2008) and Van Reenen et al. (2008) advocate that the isobaric heating event was a widespread phenomena and hence the effects should be evident in most rocks. This is clearly not the case. If one was to argue that the heating event could have been a localized phenomena it could potentially explain why some rocks did not experience the thermal overprint. However, the sample Perchuk et al. (2008) used to derive the isobaric heating portion of their $P-T$ path was collected from the Verbaard locality, less than $200 \mathrm{~m}$ away from where the sample in this study was collected.

Irrespective of the arguments pertaining to the exact shape of the $P-T$ paths reported from different workers there are important interpretative considerations to make in respect to other data sets. For example, the geochronological data of Zeh et al. (2007) and Gerdes and Zeh (2009) clearly demonstrates that the parts of the $\mathrm{CZ}$, in particular the Sand River Gneiss, have undergone polymetamorphism. Therefore the data presented in this paper and that from Zeh et al. (2004) cannot argue for a single metamorphic event, based purely on $P-T$ paths alone. Combining the geochronological data with the $P-T$ path information yields a potential paradox. The Sand River Gneiss has undergone two metamorphic events (c. 2.6 and c. $2.0 \mathrm{Ga}$ ) yet the pelites only preserve a single clockwise $P-T$ path indicative of only one metamorphic event. Gerdes and Zeh (2008) argue that the depositional age of the metasediments is questionable and they may only preserve one metamorphic event because they were deposited after the $2.6 \mathrm{Ga}$ event. Even without geochronological data one can argue that the $P-T$ path from this study and that of Zeh et al. (2004) formed during the $2.0 \mathrm{Ga}$ event. The rationale behind this is based on the preserved zoning profiles in each case. If, for example, they had formed during the $2.6 \mathrm{Ga}$ event it is highly unlikely that the growth zoning would have been preserved. The rocks would have resided at granulite facies temperatures for $600 \mathrm{Ma}$ prior to the $2.0 \mathrm{Ga}$ event. Considering this long period of time and high-cation diffusion rates (e.g. Harley, 1989) at such temperatures, the samples would have re-equilibrated and the growth zoning would have been destroyed. This process may also explain why the metapelites do not preserve a $2.6 \mathrm{Ga}$ event. Even if they had undergone an Archean tectono-metamorphic event, the subsequent Palaeoproterozoic event may have destroyed the earlier mineral assemblages. Metapelites are more sensitive to changes in P/T (e.g. Spear, 1993) than the rocks which make up the Sand River Gneiss. Therefore they are potentially more conducive to alteration and the subsequent removal of a previous history. These are, however, speculative interpretations that require substantiating with additional evidence.

Interpretative speculations aside, the data presented in this study, in conjunction with that from Zeh et al. (2004), strongly suggests that the isobaric heating event recorded by Perchuk et al. (2008), and their subsequent interpretations are erroneous. However, this raises an important issue. Why do rocks from the same area yield different results? The answer to this question can be ad- dressed by a critical assessment of the thermobarometric methods employed.

\subsection{Pseudosection thermobarometry versus conventional thermobarometry - a general discussion}

The development of the pseudosection approach to thermobarometry has, in no uncertain terms, revolutionized metamorphic petrology. Numerous workers have demonstrated that is it an extremely powerful and useful method for providing detailed $P-T-$ $X$ information for a variety of metamorphic environments (e.g. Powell et al., 1998; Vance and Mahar, 1998; White et al., 2001; Cononolly and Petrini, 2002; White et al., 2002; White et al., 2003; Zeh et al, 2004; Harris et al., 2004; White et al., 2004; Evans, 2004; Johnson and Brown, 2004; Pelletier et al., 2005; White et al., 2005; Kelsey et al., 2005; Stipska and Powell, 2005; Zeh et al. 2005a,b; Konrad-Schmolke et al., 2006; Tenczer et al., 2006; Dziggel et al., 2006; White et al., 2007; Diener et al., 2007; Powell and Holland, 2008; White et al., 2008; Millonig et al., 2008; Diener et al., 2008; Kelsey et al., 2008; Mahan et al., 2008). A recent paper by Powell and Holland (2008) discusses at the length the advantages and disadvantages of a pseudosection approach in comparison to a conventional thermobarometric approach. In light of the present discussion some of the main points from Powell and Holland (2008) need to be re-iterated. Conventional thermobarometry uses only the equilibrium thermodynamics of balanced reactions between end-members minerals, combined via an appropriate activity-composition model to the observed mineral compositions. Conversely, pseudosections are quantitative phase diagrams constructed for a single bulk-rock composition that enable the mineral compositions and modal proportions of stable mineral assemblages to be calculated as a function of $P-T$ or $T / P-X$, where $X$ represents a bulk compositional variable such as $\mathrm{H}_{2} \mathrm{O}$ or $\mathrm{Fe} /(\mathrm{Fe}+\mathrm{Mg})$. The main advantage of the pseudosection approach is that the bulk-compositional parameter provides additional constraints on $P-T$ that are not available in conventional thermobarometry (Powell and Holland, 2008). Pseudosections are able to calculate the position in $P-T$ space of a field that corresponds to a stable mineral assemblage for a given bulk-composition. Furthermore, the pseudosection illustrates where 'new' minerals are added and 'old' ones are lost from the assemblage.

Pseudosection modelling can be conducted in model chemical systems that approach 'real' bulk-rock compositions (White et al., 2007; Diener et al., 2008; Powell and Holland 2008). At present, this is the MnNCKFMASHTO system, which comprehensively covers the major chemical components found in most rock types. Conventional thermobarometry cannot provide information about the stability of a given mineral assemblage as a function of the bulk rock composition. Furthermore, conventional thermobarometric approaches commonly do not take into account the potential effects of other chemical components in the system. For example, consider the garnet-clinopyroxene Fe-Mg exchange thermometer. The Krogh (2000) calibration is based on multiple regression analysis of 'directly-calibrated' i.e. experimentally determined $\mathrm{Fe}-\mathrm{Mg}$ exchange in garnet and clinopyroxene as a function of $P, T$ and composition. The Krogh (2000) calibration does take into account the potential effect that the presence of $\mathrm{Ca}$ and $\mathrm{Mn}$ in garnet has on the Fe-Mg exchange equilibrium, however, it ignores $\mathrm{Fe}^{3+}$. Proyer et al. (2004) demonstrated how drastic this exclusion can be. Proyer et al. (2004) used Mössbauer spectroscopy to demonstrate that the $\mathrm{Fe}^{3+/} \mathrm{Fe}$ total in omphacite was significantly higher than the value obtained from standard mineral-formula recalculation. When the activities were corrected for $\mathrm{Fe}^{3+}$, the Krogh (2000) thermometer yielded a temperature of $606{ }^{\circ} \mathrm{C}$ compared to a temperature of $840{ }^{\circ} \mathrm{C}$ from the uncorrected calibration. However, this problem is not just inherent to the conventional approach. 
Estimated $\mathrm{Fe}^{3+}$ contents for bulk-compositions used in pseudosection modelling will have a similar effect on the $P-T$ location of phase stability fields. However, the effect can be quantified by calculating an $\mathrm{Fe}^{3+}$ versus $T / P$ section (Diener, pers comm.).

Even if the presence and subsequent effects of minor chemical components are taken into account in conventional thermobarometry, its application is still limited to high-variance mineral assemblages. Conversely, the pseudosection approach can be applied to a wide range of rocks, irrespective of the variance. Consider the following mineral assemblage developed in a pelitic rock (MM184) from the Etive thermal aureole, Scotland (Droop and Moazzen, 2007; Rigby et al., 2008d): and + cd + ksp + bi. How can conventional thermobarometry determine the $P-T$ conditions of equilibration for this assemblage? The use of petrogenetic grid or experimentally located equilibria will enable one to demonstrate that the sample equilibrated somewhere within the andalusite field and up-temperature of the muscovite + quartz breakdown reaction (Fig. 8A). At $1 \mathrm{kbar}$, under water-saturated conditions, temperature estimates range from 460 to $790^{\circ} \mathrm{C}$. This approach yields little information regarding $P-T$ conditions nor does it take into account the presence of cordierite and biotite in the assemblage. Fig. $8 \mathrm{~B}$ is a rather simple pseudosection constructed in KFMASH, however, it does delineate the $P-T$ stability field of the assemblage developed in sample MM184. At $1 \mathrm{kbar}$, under watersaturated conditions, the assemblage is stable from 580 to $635^{\circ} \mathrm{C}$ - a drastic improvement on the conventional estimate. This example illustrates that conventional thermobarometry is a reductionist method, which selects individual equilibria or a group of equilibria to determine $P-T$ conditions. Whereas the pseudosection approach is holistic; it takes into account the stability of the assemblage as a whole. A crucial aspect of this ideology is that even if conventional thermobarometry is able to accurately determine $P-T$ conditions in certain circumstances, it cannot provide reliable information pertaining to high-grade metamorphic processes, such as those that involve partial melting. In granulite-facies terranes melt is an integral part of the system and it must be evaluated. The advent of White et al. (2001) melt model enables for the first time 'real' rock systems to be accurately assessed. The presence or absence of a melt phase can have a profound effect on the evolution and stability of mineral assemblages (White et al., 2001; White and Powell, 2002; White et al., 2004; Diener et al., 2008). In the absence of a melt phase, below the onset of partial melting, mineral assemblages are saturated with respect $\mathrm{H}_{2} \mathrm{O}$ (e.g. Powell, 1983; Harley et al., 2002; Rigby et al., 2008d; Rigby and Droop, 2008). At suprasolidus conditions, the metamorphic fluid is lost via partitioning into the melt phase (e.g. Powell, 1983; Clemens and Droop, 1998; Harley and Carrington, 2001) and at progressively higher temperatures the solid assemblage is characterized by predominantly anhydrous minerals (Stevens and Clemens, 1993; White and Powell, 2002; Droop et al., 2003). If melt remains in contact with the rock during retrogression then once the melt starts to crystallize it will expel $\mathrm{H}_{2} \mathrm{O}$ leading to the rehydration and replacement of high-grade assemblages (Van Reenen, 1986; Stevens, 1997; White and Powell, 2002). The preservation of granulite facies assemblages implies there is a lack of rehydration and hence there must have been substantial melt loss from the system (White and Powell, 2002). Melt loss not only has the effect of preserving or destroying granulite-facies assemblages but it inevitably leads to changes in the bulk composition of a rock by removing $\mathrm{H}_{2} \mathrm{O}$, $\mathrm{Na}_{2} \mathrm{O}, \mathrm{K}_{2} \mathrm{O}$ and $\mathrm{CaO}$ (White and Powell, 2002; White et al., 2004; Diener et al., 2008) and leaving a preferentially FeO-MgO enriched residuum (Diener et al., 2008). For reasons discussed above, the addition of a bulk-compositional constraint, inherent to the pseudosection approach, is a major advantage for $P-T$ modelling. However, with the potential for change in the bulk-composition brought about by melt loss, it may also be the source of its greatest weakness, if unaccounted for. Thus the selection of an appropriate bulk-composition, in addition to an adequate model chemical system, is perhaps the most important parameter to constrain when attempting to calculate a pseudosection (White et al., 2007). The effects of potential melt loss and/or subsequent variations in $\mathrm{MH}_{2} \mathrm{O}$ can, however, be addressed by calculating either $\mathrm{T}-\mathrm{MH}_{2} \mathrm{O}$ and T-melt loss diagrams for a desired pressure range (e.g. White et al., 2001; White and Powell, 2002) or by re-integrating potential melt loss via the method of White et al. (2004). In short, not only do pseudosections provide a more robust and accurate assessment of $P-T$ conditions but they can also yield vital information pertaining to high-grade metamorphic processes that a conventional approach cannot obtain.

If the pseudosection approach to thermobarometry is vastly superior, where does it leave its conventional counterparts? O’Brien (2008), Harley (2008) and Powell and Holland (2008) pose
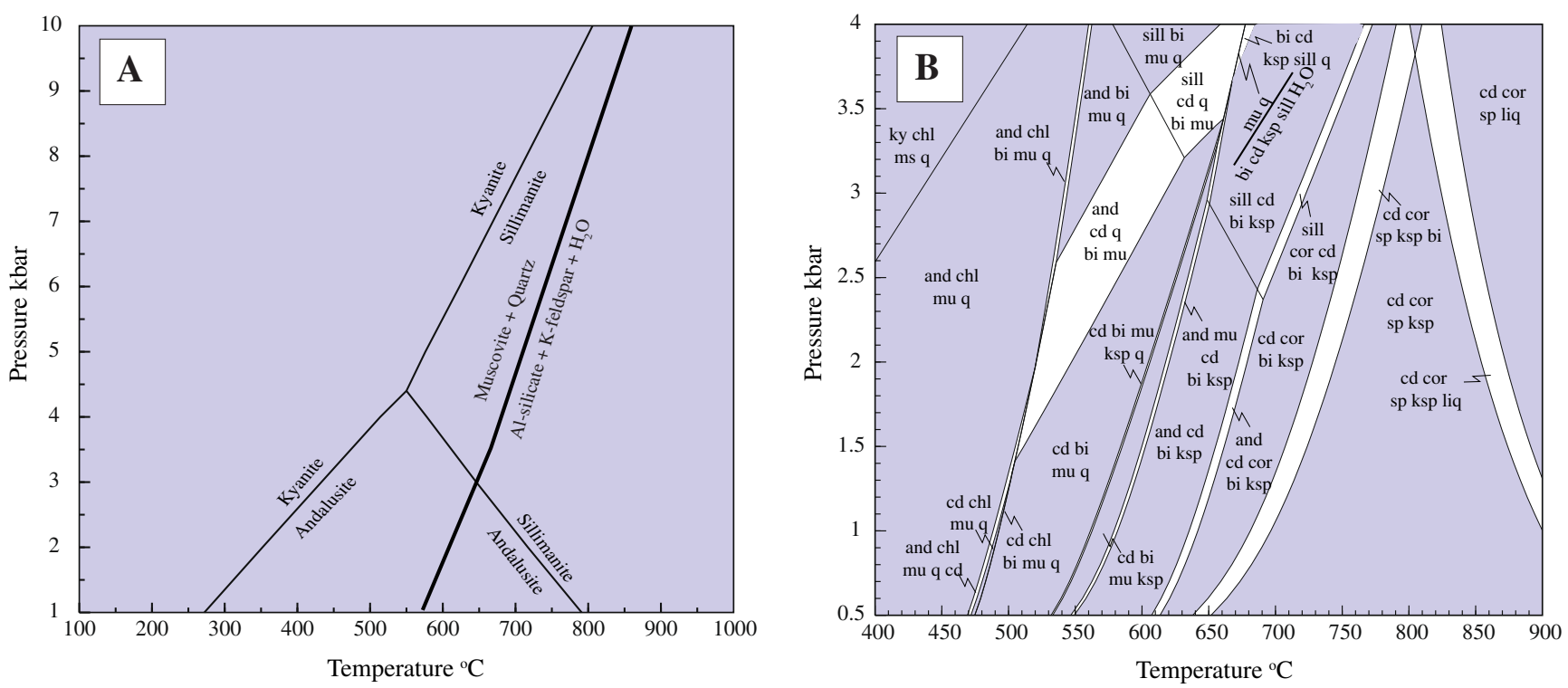

Fig. 8. (A) Conventional method for determining $P-T$ conditions of sample MM184. (B) A simplified KFMASH pseudosection for sample MM184. 
a similar question: In the era of pseudosections does conventional thermobarometry still have a role to play? The answer is yes, in certain circumstances. For example, where pseudosection analysis may calculate relatively large $P-T$ stability fields for certain mineral assemblages or when rocks contain minerals or chemical components that are not currently present in the THERMOCALC database e.g. Kornerupine in granulites from East Antartica (Kelly and Harley, 2004) or $\mathrm{Zr}$ in rutile thermometry (Thompkins et al., 2007). In fact, despite arguing for the superior nature of pseudosections, Powell and Holland (2008) actually advocate the use of a combined conventional and pseudosection approach, providing that the same activity-composition models and thermodynamic datasets are used for both methods. In spite of this amicable conclusion, one must face fact. The pseudosection approach to thermobarometry is unequivocally superior and as the thermodynamic database continues to improve and new activity-models are devised, conventional approaches will continue to become detached from modern metamorphic petrology.

6.4. Pseudosections versus the local mineral equilibrium approach of Perchuk et al. (2008): a method-specific discussion

The above discussion was a general comparison between pseudosections and conventional thermobarometry. The following is a critical assessment of the Perchuk et al. (2008) method, which is necessary for explaining the different results produced by different methods. Zeh and Klemd (2008) responded to the Perchuk et al. (2008) paper with a number of criticisms. The following arguments presented here are what I conceive to be main problems, none of which were addressed in full by Zeh and Klemd (2008).

Many of the problems outlined in the previous discussion section are applicable to the method of Perchuk et al. (2008). For example, a reliance on $\mathrm{Fe}-\mathrm{Mg}$ exchange thermometers, ignoring the role of a melt phase and conducting modelling in a simplified chemical system. However, the method proposed by Perchuk et al. (2008) is not just conventional thermobarometry per se. There are some serious method-specific problems that need addressing.

(i) Matching mineral compositions: are they really in equilibrium?

Perchuk et al. (2008) postulate that the mineral assemblages preserved in polymetamorphic rocks of the Central Zone formed during M1 and the compositions of the minerals were subsequently re-equilibrated during $\mathrm{M} 2$, which was associated with no new mineral growth. The apparent absence of diagnostic M2 mineral assemblages and a lack of textural information to support equilibrium led the aforementioned authors to rely solely on compositional zoning profiles to derive $P-T$ estimates. In essence, the Perchuk et al. (2008) method uses detailed microprobe data to 'match' compositions of minerals that should be in equilibrium at an arbitrary $T$ value. Once 'matching' or 'locally equilibrated' compositions are found for a complimentary mineral pair (e.g. garnet and biotite) then a conventional thermometer (e.g. Grt-Bt, Fe$\mathrm{Mg}$ exchange thermometry) is used to derive the $T$ of equilibration. This $T$ value is then used to constrain $a \mathrm{H}_{2} \mathrm{O}, P$ and the composition of other minerals in the assemblage (e.g. $X_{M g}^{C r d}$ ). The major problem with this approach is self-evident. Are compositionally compatible mineral pairs in equilibrium, even if they are now or always were spatially distant? Possibly, however, there is no robust scientific method available to accurately assess this potential pitfall. 'Matching' compositions from one domain to another in a thin-section is tantamount to arguing that a garnet composition from a Namaqualand granulite was once in equilibrium with a compatible biotite composition from a granulite in the Limpopo Belt. The local equilibrium approach introduces an element of uncertainty that cannot be quantified. The high $P-T$ conditions determined by Perchuk et al. (2008) from the cores of minerals yield estimates that are in agreement with other workers (e.g. Droop, 1989; Zeh et al. 2004), suggesting that local equilibrium may have been attained. However, the subsequent $P-T$ path is questionable, but it does have a plausible explanation. Frost and Chacko (1989) introduced a concept known as Granulite Uncertainty Principle, which suggests that conventional thermobarometers have closure temperatures below those of granulite facies metamorphism, thus casting doubt on the reliability of these methods. Moreover, Frost and Chacko (1989) advocate that the low closure temperature of ion-exchange thermometers (particularly those based on Fe-Mg exchange) also calls into question the validity of $P-T$ paths calculated from garnet zoning profiles. The reliance on zoning profiles and the use of $\mathrm{Fe}-\mathrm{Mg}$ exchange equilibria in a granulite-facies terrane is the greatest downfall of the Perchuk et al. (2008) $P-T$ path, which may, in part, be an artifact formed as a result of using mineral compositions that are not in equilibrium but are diffusion-controlled. The pseudosection approach negates the diffusion problem as it does not rely solely on mineral compositions but is able to determine the $P-T$ stability of a given mineral assemblage.

\section{(ii) Compositional isopleths}

The $P-T$ path defined by Perchuk et al. (2008) is defined by various compositional isopleths for garnet, biotite, cordierite and orthopyroxene. As outlined above, these isopleths may be prone to inaccuracies due to the potential diffusion related problem. However, in spite of this, the calculated isopleths of Perchuk et al. (2008) are not constrained for a particular mineral assemblage or a group of mineral assemblages. The gradient for each compositional isopleth calculated by Perchuk et al. (2008) varies. However, each isopleth represents a linear curve that spans a wide $P-T$ range e.g. Garnet ${ }_{25}$ stretches from $550^{\circ} \mathrm{C}$ at $\sim 3.9$ kbar to $800^{\circ} \mathrm{C}$ at 6 kbar. Examination of Fig. 6D reveals that the gradient or $P-T$ position of any given isopleth changes orientation when moving from one stability field to the next. The field stability boundaries on a pseudosection represent the $P-T$ positions at which a phase is lost or gained from the system. Consider the following hypothetical situation in which a Fe-Mg bearing phase (e.g. opx) is added to the following assemblage sill, q, ksp pl, liq, bi, g. Prior to the addition of opx the amount of Fe-Mg in the bulk-composition will be distributed, primarily, between $g$ and bi. However, with the addition of opx to system the Fe-Mg ratio of $g$ and/or bi will change in order to accommodate the new phase. Consequently, calculated $\mathrm{Fe}-\mathrm{Mg}$ isopleths for the $\mathrm{g}$ or bi will also change when entering a new stability field. The isopleths calculated by Perchuk et al. (2008) do not consider the mineralogical changes (lose or gain of a phase) that will inevitably occur across the $P-T$ range $550{ }^{\circ} \mathrm{C}$ at $\sim 3.9 \mathrm{kbar}$ to $800{ }^{\circ} \mathrm{C}$ at 6 kbar. Compositional isopleths must be constrained for individual stability fields that represent a given mineral assemblage.

\subsection{The way forward?}

The above discussion has focused on upon the relative merits of a pseudosection versus a conventional thermobarometric approach in addition to the method-specific approach of Perchuk et al. (2008). The above discussion strongly argues for a pseudosection approach. Whilst this approach is clearly superior it is not without fault. Quantifying multiple melt loss events throughout a polymetamorphic history appears to be the most pressing issue related to deriving reliable $P-T$ paths from rocks of pelitic composition (e.g. Diener et al., 2008). An alternative approach would be that of Mahan et al. (2008), who succeeded in unambiguously demonstrating polymetamorphism in mafic granulites from Athabasca terrane in 
the western Canadian Shield using NCFMASHT pseudosections. In order to avoid potential melt-loss related problems it would be advisable to adopt this approach and model mafic granulites from the Central Zone of the Limpopo Belt.

\section{Conclusions}

(1) $P-T$ pseudosections constructed in suitable model chemical systems for rocks of different bulk-composition are able to accurately constrain a $P-T$ path that is consistent with the modes, compositions and zonations in the observed mineral assemblages.

(2) The $P-T$ results of this study conform to those obtained by Zeh et al. (2004) indicating that rocks of the CZ around the Messina area under went a single clockwise metamorphic evolution that was characterized by an early high-pressure phase at $10-11 \mathrm{kbar} / 800^{\circ} \mathrm{C}$, followed by a simultaneous pressure decrease and temperature increase to $\sim 8 \mathrm{kbar} /$ $850{ }^{\circ} \mathrm{C}$ and subsequent retrogression via decompressioncooling to $4-5 \mathrm{kbar}$ at $T<650^{\circ} \mathrm{C}$.

(3) The results of this study and that of Zeh et al. (2004) are, however, inconsistent with a twofold metamorphic $P-T$ path proposed by Perchuk et al. (2008).

(4) Discrepancies in the results obtained from the different studies are a consequence of using two different thermodynamic methods.

(5) The strengths and weaknesses of each method suggest that pseudosection modelling provides, at present, the most robust and powerful method for determining $P-T$ conditions (c.f. Powell and Holland, 2008).

(6) Pseudosection modelling of mafic granulites will potentially avoid any problems related to melt-loss.

\section{Acknowledgements}

Martin Rigby would like to thank the University of Pretoria for providing a research development grant (RDP-AM354) that enabled this research to be conducted. Martin Rigby would also like to thank Dirk Van Reenen and Rene Boshoff for organizing a Limpopo Field Workshop, which provided the stimulus for writing this paper. Furthermore, despite our disagreements, Dirk Van Reenen and Leonid Perchuk are thanked for their fruitful, albeit, heated discussions pertaining to the metamorphic evolution of the Limpopo Belt. Gary Stevens and Armin Zeh are thanked for their thorough and constructive reviews, which greatly improved the clarity of the arguments expressed within the manuscript. Pat Eriksson is also thanked for the editorial handling.

\section{References}

Barton Jr., J.M., 1996. The Messina layered intrusion, Limpopo Belt, South Africa: an example of in situ contamination of Archean anorthosite complex by continental crust. Precambrian Research 78, 139-150.

Barton, J.M., Sergeev, S., 1997. High precision, U-Pb analyses of single grains of zircon from quartzite in the Beit Bridge Group yield a discordia. South African Journal of Geology 100, 37-41.

Barton, J.M., Holzer, L., Kamber, B., Doig, R., Kramers, J.D., Nyfeler, D., 1994. Discrete metamorphic events in the Limpopo belt, Southern Africa: implications for the application of $P-T$ paths in complex metamorphic terranes. Geology 22, 10351038.

Berger, M., Kramers, J.D., Nagler, T.F., 1995. An Archaean high grade province adjacent to a granite greenstone terrain: geochemistry and geochronology of charnoenderbites in the Northern Marginal Zone of the Limpopo Belt, Southern Africa and genetic models. Schweizerische Mineralogische und Petgrographische Miteilungen 75, 17-42.

Blenkinsop, T.G., Mkweli, S., 1992. The relation between the Zimbabwe Craton and the North Marginal Zone of the Limpopo. In: Third Symposium on Science and Techonology. Research Council of Zimbabwe.

Blenkinsop, T.G., Kroner, A., Chiwara, V., 2004. Single stage, late Archean exhumation of granulites in the Northern Marginal, Limpopo Belt, Zimbabwe, and relevance to gold mineralization at Renco Mine. South African Journal of Geology 100, 377-396.

Boshoff, R., Van Reenen, D.D., Kramers, J.D., Smit, C.A., Perchuk, L.L., Armstrong, R. 2006. Geologic History of the Central Zone of the Limpopo Complex: The West Alldays Area. The Journal of Geology 114, 699-716.

Brandl, G., 1983. Geology and geochemistry of various supracrustal rocks of the Beit Bridge Complex east of Messina. Special Publication of the Geological Society of South Africa 8, 103-112.

Buick, I.S., Hermann, J., Williams, b.I.S., Gibson, R.G., Rubatto, D., 2006. A SHRIMP U$\mathrm{Pb}$ and LA-ICP-MS trace element study of the petrogenesis of garnet-cordieriteorthoamphibole gneisses from the Central Zone of the Limpopo Belt, South Africa. Lithos 88, 150-172.

Bumby, A.J., van der Merwe, R., 2004. The Limpopo Belt of southern Africa: an overview. In: Tempos and Events in Precambrian Time. Elsevier, Amsterdam, pp. 217-222.

Bumby, A.J., Eriksson, P.G., van der Merwe, R., Brumer, J.J., 2001. Shear-zone controlled basins in the Blouberg area, Northern Province, South Africa: synand post-tectonic sedimentation relating to c. $2.0 \mathrm{Ga}$ reactivation of the Limpopo Belt. Journal of African Earth Sciences 33, 445-461.

Chudy, T.C., Zeh, A., Gerdes, A., Klemd, R., Barton, J.M., 2009. Palaeoarchaean (3.3 Ga) mafic magmatism and Palaeoproterozoic (2.02 Ga) amphibolite-facies metamorphism in the Central Zone of the Limpopo Belt: New Geochronological, Petrological and Geochemical Constraints from Metabasic Rock and Metapelitic Rocks from the Venetia Area. South African Journal of Geology 11, 387-408.

Clemens, J.D., Droop, G.T.R., 1998. Fluid, $P-T$ paths and the fates of anatectic melts in the Earth's crust. Lithos 44, 21-36.

Cononolly, J.A.D., Petrini, K., 2002. An automated strategy for calculation of phase diagram sections and retrieval of rock properties as a function of physical conditions. Journal of Metamorphic Geology 20, 697-708.

Diener, J.F.A., Powell, R., White, R.W., Holland, T.J.B., 2007. A thermodynamic mode for clino- and orthoamphiboles in the system $\mathrm{N}_{2} \mathrm{O}-\mathrm{CaO}-\mathrm{FeO}-\mathrm{MgO}-\mathrm{Al}_{2} \mathrm{SiO}_{3}-$ $\mathrm{SiO}_{2}-\mathrm{H}_{2} \mathrm{O}-\mathrm{O}$. Journal of Metamorphic Geology 25, 631-656.

Diener, J.F.A., White, R.W., Powell, R., 2008. Granulite facies metamorphism and subsolidus fluid-absent reworking, Strangeways Range, Arunta Block, central Australia. Journal of Metamorphic Geology 26, 603-622.

Droop, G.T.R., 1987. A general equation for estimating $\mathrm{Fe}^{3+}$ concentrations in ferromagnesian silicates and oxides using stoichiometric criteria. Mineralogical Magazine 51, 431-437.

Droop, G.T.R., 1989. Reaction history of garnet-sapphirine granulites and conditions of Archaean high-pressure granulite-facies metamorphism in the Centra Limpopo Mobile Belt, Zimbabwe. Journal of Metamorphic Geology 7, 383-403.

Droop, G.T.R., Moazzen, M., 2007. Contact metamorphism and partial melting of Dalradian pelites and semipelites in the southern sector of the Etive aureole. Scottish Journal of Geology 43, 1-25.

Droop, G.T.R., Clemens, J.D., Dalrymple, D.J., 2003. Processes and conditions during contact anatexis, melt escape and resitite formation: the Huntly Gabbro Complex, NE Scotland. Journal of Petrology 60, 1-35.

Du Toit, M.C., Van Reenen, D.D., Roering, C., 1983. Some aspects of the geology, structure and metamorphism of the southern marginal zone of the Limpopo metamorphic complex. Special Publication of the Geological Society of South Africa 8, 121-142.

Dziggel, A., Knipfer, S., Kisters, A.F.M., Meyer, F.M., 2006. $P-T$ and structural evolution during exhumation of high- $T$, medium- $P$ basement rocks in the Baberton Mountain Land, South Africa. Journal of Metamorphic Geology 24, 535-551

Eriksson, P.G., Banerjee, S., Nelson, D.R., Rigby, M.J., Catuneanu, O., Sarkar, S. Roberts, R.J., Ruban, D., Mtimkulu, N.M., Sunder Raju, P.V., 2009. A Kaapvaal craton gebate: nucleus of an early small supercontinent or affected by an enhanced accretion event? Gondwana Research 15, 354-372.

Evans, T.P., 2004. A method for calculating effective bulk composition modification due to due to crystal fractionation in garnet bearing schist: implications for isopleth thermobarometry. Journal of Metamorphic Geology 22, 547-557.

Frost, R.B., Chacko, T., 1989. The granulite uncertainty principle: limitations of thermobarometry in granulites. Journal of Geology 97, 435-450.

Gerdes, A., Zeh, A., 2009. Zircon formation versus zircon alteration - new insights from combined U-Pb and Lu-Hf in situ LA-ICP-MS analyses, and consequences for the interpretation of Archean zircon from the Limpopo Belt. Chemical Geology.

Harley, S.L., 1989. The origin of granulites: a metamorphic perspective. Geological Magazine 126, 215-247.

Harley, S.L., 2008. Refining the $P-T$ records of UHT crustal metamorphism. Journal of Metamorphic Geology 26, 125-154.

Harley, S.L., Carrington, D.P., 2001. The distribution of $\mathrm{H}_{2} \mathrm{O}$ between cordierite and granitic melt: $\mathrm{H}_{2} \mathrm{O}$ incorporation in cordierite and its application to high-grade metamorphism and crustal anatexis. Journal of Petrology 42, 1595-1620.

Harley, S.L., Thompson, P., Henson, B.J., Buick, I.S., 2002. Cordierite as a sensor of fluid conditions in high-grade metamorphism and crustal anatexis. Journal of Metamorphic Geology 20, 71-86.

Harris, N.B.W., Holland, T.J.B., 1984. The significance of cordierite-hypersthene assemblages from the Beitbridge region of the Central Limpopo Belt; evidence for rapid decompression in the Archean? American Mineralogist 69, 10361049.

Harris, N.B.W., Caddick, M., Kosler, J., Goswami, S., Vance, D., Tindle, A.G., 2004. The pressure-temperature-time path of migmatites from the Sikkim Himalaya Journal of Metamorphic Geology 22, 249-262. 
Hisada, K., Miyano, T., 1996. Petrology and microthermometry of aluminous rocks in the Botswanan Limpopo Central Zone: evidence for isothermal decompression and isobaric cooling. Journal of Metamorphic Geology 14 183-197.

Hisada, K., Perchuk, L.L., Gerya, T.V., Van Reenen, D.D., Paya, B.K., 2005. P-T-fluid evolution in the Mahalapye Complex, Limpopo high-grade terrane, eastern Botswana. Journal of Metamorphic Geology 23, 313-334.

Hofmann, A., Kroner, A., Brandl, G., 1998. Field relationships of mid- to late Archean high-grade gneisses of igneous and sedimentary parentage in the Sand River, Central Zone of the Limpopo Belt, South Africa. South African Journal of Geology $101,185-200$.

Holland, T.J.B., Powell, R., 1998. An internally consistent thermodynamic data set of petrological interest. Journal of Metamorphic Geology 16, 309-343.

Holzer, L., 1995. The magmatic petrology of the Bulai pluton and the tectonometamorphic overprint at ca. $2.0 \mathrm{Ga}$ in the Central Zone of the Limpopo Belt, Southern Africa. Unpublished M.Sc. Thesis. University of Bern.

Holzer, L., Frei, R., Barton, J.M., Kramers, J.D., 1998. Unravelling the record of successive high grade events in the Central Zone of the Limpopo Belt using $\mathrm{Pb}$ single phase dating of metamorphic minerals. Precambrian Research 87, 87115.

Jaeckel, P., Kroner, A., Kamo, S.L., Brandl, G., Wendtk, J.I., 1997. Late Archaean to early Proterozoic granitoid magmatism and high-grade metamorphism in the central Limpopo belt, South Africa. Journal of the Geological Society of London 154, 25-44.

Johannes, W., Holtz, F., 1996. Petrogenesis and Experimental Petrology of Granitic Rocks. Springer Verlag, Berlin.

Johnson, T.E., Brown, M., 2004. Quantitative constraints on metamorphism in the Variscides of Southern Brittany - a complimentary pseudosection approach. Journal of Petrology 45, 1237-1259.

Kamber, B.S., Blenkinsop, T.G., Villa, I.M., Dahl, P.S., 1995. Proterozoic transpressive deformation in the Northern Marginal Zone, Limpopo Belt, Zimbabwe. Journal of Geology 100, 490-508.

Kelly, N.M., Harley, S.L., 2004. Orthopyroxene-Corundum in Mg-Al-rich Granulites from the Oygarden Islands, East Antartica. Journal of Petrology 45, 1481-1512.

Kelsey, D.E., White, R.W., Powell, R., 2005. Calculated phase equilibria in $\mathrm{K}_{2} \mathrm{O}-\mathrm{FeO}$ $\mathrm{MgO}-\mathrm{Al}_{2} \mathrm{O}_{3}-\mathrm{SiO}_{2}-\mathrm{H}_{2} \mathrm{O}$ for silica-undersaturated sapphirine-bearing mineral assemblages. Journal of Metamorphic Geology 23, 217-239.

Kelsey, D.E., Clark, C., Hand, M., 2008. Thermobarometric modelling of zircon and monazite growth in melt-bearing systems: examples using model metapelitic and metapsammitic granulites. Journal of Metamorphic Geology 26, 199-212.

Klemd, R., Schmidt, A., Martin, J., Barton, J.M., 2003. P-T path constraints from metapeletic rocks east of the Venetia kimberlite pipes, Central Zone, Limpopo belt, South Africa: have these rocks seen granulite-facies conditions? South African Journal of Geology 106, 129-148.

Konrad-Schmolke, M., Babist, J., Handy, M.R., O’Brien, P.J., 2006. The physicochemical properties of a subducted slab from garnet zonation patterns (Seisa Zone, Western Alps). Journal of Petrology 47, 2123-2148.

Kreissig, K., Holzer, L., Frei, R., et al., 2001. Geochronology of the Hout River Shea Zone and the metamorphism of the Limpopo belt, Southern Africa. Precambrian Research 109, 145-173.

Krogh, E., 2000. The garnet-clinopyroxene $\mathrm{Fe}^{2+}-\mathrm{Mg}$ geothermometer: an updated calibration. Journal of Metamorphic Geology 18, 211-219.

Kroner, A., Nemchin, A.A., Jaeckel, P., Hofmann, A., Brandl, G., Pidgeon, R.T., 1998 Field relationships and age of supracrustal Beit Bridge Complex and associated granitoid gneisses in the Central Zone of the Limpopo Belt, South Africa. South African Journal of Geology 101, 201-213.

Kroner, A., Jaeckel, P., Brandl, G., Nemchin, A.A., Pidgeon, R.T., 1999. Single zircon ages for granitoid gneisses in the Central Zone of the Limpopo Belt, Southern Africa and geodynamic significance. Precambrian Research 93, 299-337.

Le Breton, N., Thompson, A.B., 1988. Fluid-absent (dehydration) melting of biotite in metpelites in the early stages of crustal anatexis. Contributions to Mineralogy and Petrology 99, 226-237.

Mahan, K.H., Goncalves, P., Flowers, R., Williams, M.L., Hoffman-Setka, D., 2008. The role of heterogeneous strain in the development and preservation of a polymetamorphic record in high- $P$ granulites, western Canadian Shield. Journal of Metamorphic Geology 26, 669-694.

McCourt, S., Armstrong, R., 1998. SHRIMP U-Pb zircon geochronology of granites from the Central Zone of the Limpopo Belt, southern Africa: Implications for the age of the Limpopo Orogeny. South African Journal of Geology 101 (4), 329-338.

McCourt, S., Vearncombe, J.R., 1992. Shear Zones of the Limpopo Belt and adjacent granitoid-greenstone terranes, implications for late Archaean collision tectonics in Southern Africa. Precambrian Research 55, 553-570.

Millonig, L., Zeh, A., Gerdes, A., Klemd, R., 2008. Late Archaean high-grade metamorphism in the Central Zone of the Limpopo Belt (South Africa) Petrological and geochronological evidence from the Bulai Pluton. Lithos 103, 333-351.

O'Brien, P.J., 2008. Challenges in high-pressure granulites metamorphism in the era of pseudosections: reaction textures, compositional zoning and tectonic interpretation with examples from the Bohemian Massif. Journal of Metamorphic Geology 26, 235-251.

Pelletier, A., Guiraud, M., Menot, R.P., 2005. From partial melting to retrogression in the Ponte Geologie migmatitic complex: a history of heterogeneous distribution of fluids. Lithos 81, 153-166.

Perchuk, L.L., Gerya, T.V., van Reenan, D.D., Krotov, A.V., Safonov, O.G., Smit, C.A., Shur, M.Y., 2000. Comparative petrology and metamorphic evolution of the
Limpopo (South Africa) and Lapland (Fennoscandia) high-grade terrains. Mineralogy and Petrology 69, 69-107.

Perchuk, L.L., Gerya, T.V., van Reenan, D.D., Smit, C.A., 2006. P-T paths and a problem of high-temperature polymetamorphism. Petrology 14, 117-153.

Perchuk, L.L., van Reenan, D.D., Varlamov, D.A., van Kal, S.M., Tabatabaeimanesh, Boshoff, R., 2008. $P-T$ record of two high-grade metamorphic events in the Central Zone of the Limpopo Complex, South Africa. Lithos 103, 70-105.

Pouchou, J.L., Pichoir, F., 1991. Quantitative analysis of homogeneous or stratified microvolumes applying the model "PAP". In: Heinrich, K.F.J., Newbury, D.E. (Eds.), Electron Probe Quantitation. Plenum Press, New York.

Powell, R., 1983. Fluids and melting in upper amphibolite facies conditions. Geological Society of London Journal 140, 629-634.

Powell, R., Holland, T.J.B., 1988. An internally consistent thermodynamic dataset with uncertainties and correlations: 3. Application methods, worked examples and a computer program. Journal of Metamorphic Geology 6, 173-204.

Powell, R., Holland, T.J.B., 2008. On thermobarometry. Journal of Metamorphic Geology 26, 155-179.

Powell, R., Holland, T.J.B., Worley, B., 1998. Calculating phase diagrams involving solid-solutions via non-linear equations, with examples using THERMOCALC. Journal of Metamorphic Geology 16, 577-588.

Proyer, A., Dachs, E., McCammoon, C., 2004. Pitfalls in geothermobarometry of ecologites: $\mathrm{Fe}^{3+}$ and changes in the mineral chemistry of omphacite at ultrahigh pressures. Contributions to Mineralogy and Petrology 147, 305-318.

Rigby, M.J., Droop, G.T.R., 2008. The cordierite fluid monitor: case studies for and against its potential application. European Journal of Mineralogy 20, 693-712.

Rigby, M.J., Mouri, H., Brandl, G., 2008a. A review of the P-T-t evolution of the Limpopo Belt: constraints for a tectonic model. Journal of African Earth Sciences 50, 120-132.

Rigby, M.J., Mouri, H., Brandl, G., 2008b. $P-T$ conditions and the origin of quartzofeldspathic veins in metasyenites from the Central Zone of the Limpopo Belt, South Africa. South African Journal of Geology.

Rigby, M.J., Droop, G.T.R., Plant, D., Gräser, P., 2008c. Electron probe micro-analysis of oxygen in cordierite: potential implications for analysis of volatiles in minerals. South African Journal of Geology 111, 239-250.

Rigby, M.J., Droop, G.T.R., Bromiley, G., 2008d. Variations in fluid activity across the Etive thermal aureole, Scotland: evidence from cordierite volatile contents. Journal of Metamorphic Geology 26, 331-346.

Roering, C., Van Reenen, D.D., Smit, C.A., et al., 1992. Tectonic model for the evolution of the Limpopo Belt. Precambrian Research 55, 539-552.

Schaller, M., Steiner, O., Studer, I., Holzer, L., Herwegh, M., Kramers, J., 1999. Exhumation of Limpopo Central Zone granulites and dextral continent-scale transcurrent movement at $2.0 \mathrm{Ga}$ along the Palala Shear Zone, Northern Province, South Africa. Precambrian Research 96, 263-288.

Smit, C.A., Roering, C., Van Reenen, D.D., 1992. The structural framework of the southern margin of the Limpopo Belt, South Africa. Precambrian Research 55, 51-67.

Smit, C.A., Van Reenen, D.D., Gerya, T.V., Perchuk, L.L, 2001. P-T conditions of decompression of the Limpopo high-grade terrane: record from shear zones. Journal of Metamorphic Geology 19, 249-268.

Spear, F.S., 1993. Metamorphic phase equilibria and pressure-temperature-time paths. Mineralogical Society of America Monograph p. 799.

Stevens, G., 1997. Melting, carbonic fluids, and water recycling in the deep crust: an example from the Limpopo Belt, South Africa. Journal of Metamorphic Geology $15,141-154$.

Stevens, G., Clemens, J.D., 1993. Fluid-absent melting and the roles of fluids in the lithosphere: a slanted summary? Chemical Geology 108, 1-17.

Stevens, G., Van Reenen, D.D., 1992a. Constraints on the form of the P-T loop in the Southern Marginal Zone of the Limpopo Belt, South Africa. Precambrian Research 55, 279-296

Stevens, G., Van Reenen, D.D., 1992b. Constraints on the origin of metapelitic granulites in the Southern Marginal Zone of the Limpopo Belt. Precambrian Research 55, 303-319.

Stipska, P., Powell, R., 2005. Constraining the $P-T$ path of MORB-type eclogite using pseudosections, garnet zoning and garnet-clinopyroxene thermometry: an example from the Bohemian Massif. Journal of Metamorphic Geology 23, 725743.

Tenczer, V., Powell, R., Stuwe, K., 2006. Evolution of $\mathrm{H}_{2} \mathrm{O}$ content in a polymetamorphic terrane: the Plattengneiss Shear Zone, (Koralpe, Austria). Journal of Metamorphic Geology 24, 281-295.

Thompkins, H.S., Powell, R., Ellis, D.J., 2007. The pressure dependence of the zirconium-in-rutile thermometer. Journal of Metamorphic Geology 25, 703-713.

Tsunogae, T., Van Reenen, D.D., 2006. Corundum + quartz and Mg-staurolite bearing granulite from the Limpopo belt, Southern Africa: implications for a P-T path. Lithos 92, 576-587.

Van Reenen, D.D., 1986. Hydration of cordierite and hypersthene, a description of the retrograde isograd in the Limpopo Belt, South Africa. American Mineralogist 71, 900-915.

Van Reenen, D.D., Barton, J.M., Roering, C., Smit, C.A., Van Schalkwyk, J.F., 1987. Deep crustal response to continental collision: The Limpopo Belt of southern Africa. Geology 15, 11-14

Van Reenen, D.D., Roering, C., Smit, C.A., Barton Jr., J.M., 1990. The granulite facies rocks of the Limpopo Belt, South Africa. In: Vielzeuf, D., Vidal, P. (Eds.) Granulites and Crustal Evolution, NATO-ASI Series C211. Luwer, Dordrecht, pp. 257-289.

Van Reenen, D.D., Roering, C., Ashwal, L.D., de Wit, M.J., 1992. Regional geological setting of the Limpopo Belt. Precambrian Research 55, 1-5. 
Van Reenen, D.D., Perchuk, L.L., Smit, C.A., et al., 2004. Structural and $P-T$ evolution of a major cross fold in the Central Zone of the Limpopo high-grade terrain, South Africa. Journal of Petrology 45, 1413-1439.

Van Reenen, D.D., Boshoff, R., Smit, C.A., Perchuk, L.L., Kramers, J.D., McCourt, S., Armstrong, R.A., 2008. Geochronological problems related to polymetamorphism in the Limpopo Complex, South Africa. Gondwana Research 14, 644-662.

Vance, D., Mahar, E., 1998. Pressure-temperature paths from $P-T$ pseudosections and zoned garnets: potential implications and examples from the Zanskar Himalayas, MW India. Contributions to Mineralogy and Petrology 132, 225245.

Watkeys, M.K., Light, M.P.R., Broderick, T.J., 1983. A retrospective view of the Central Zone of the Limpopo belt, Zimbabwe. In: Van Biljon, W.J., Legg, J.H. (Eds.), The Limpopo Belt, vol. 8. Special Publication Geological Society of South Africa, Johannesburg, pp. 65-80.

White, R.W., Powell, R., 2002. Melt loss and the preservation of granulite facies mineral assemblages. Journal of Metamorphic Geology 20, 621632.

White, R.W., Powell, R., Holland, T.J.B., 2001. Calculation of partial melting equilibria in the system $\mathrm{Na}_{2} \mathrm{O}-\mathrm{CaO}-\mathrm{K}_{2} \mathrm{O}-\mathrm{FeO}-\mathrm{MgO}-\mathrm{Al}_{2} \mathrm{O}_{3}-\mathrm{SiO}_{2}-\mathrm{H}_{2} \mathrm{O}$ (NCKFMASH). Journal of Metamorphic Geology 19, 139-153.

White, R.W., Powell, R., Clarke, G.L., 2002. The interpretation of reaction textures in Fe-rich metapelitic granulites of the Musgrave Block, central Australia: constraints from mineral equilibria calculations in the system $\mathrm{K}_{2} \mathrm{O}-\mathrm{FeO}-$ $\mathrm{MgO}-\mathrm{Al}_{2} \mathrm{SiO}_{3}-\mathrm{SiO}_{2}-\mathrm{H}_{2} \mathrm{O}-\mathrm{TiO}_{2}-\mathrm{Fe}_{2} \mathrm{O}_{3}$. Journal of Metamorphic Geology 20, 4155.

White, R.W., Powell, R., Clarke, G.L., 2003. Prograde metamorphic assemblage evolution during partial melting of metasedimentary rocks at low pressures: migmatites from Mt Stafford, central Australia. Journal of Petrology 44, 19371960.

White, R.W., Powell, R., Halpin, J.A., 2004. Spatially-focused melt formation in aluminous pelites from Broken Hill, Australia. Journal of Metamorphic Geology $22,825-845$.
White, R.W., Pomroy, N.E., Powell, R., 2005. An in situ metatexite-diatexite transition in upper amphibolite facies rocks from Broken Hill, Australia. Journal of Metamorphic Geology 23, 579-602.

White, R.W., Powell, R., Holland, T.J.B., 2007. Progress relating to calculation of partial melting equilibria for metapelites and felsic gneisses. Journal of Metamorphic Geology 25, 511-527.

White, R.W., Powell, R., Baldwin, J.A., 2008. Calculated phase equilibria involving chemical potentials to investigate the textural evolution of metamorphic rocks. Journal of Metamorphic Geology 26, 181-198.

Windley, B.F., Ackermand, D., Herd, R.K., 1984. Sapphirine/kornerupine-bearing rocks and crustal uplift history of the Limpopo belt, Southern Africa. Contributions to Mineralogy and Petrology 86, 342-358.

Zeh, A., Klemd, R., 2008. Comments on $P-T$ record of two high-grade metamorphic events in the Central Zone of the Limpopo Complex, South Africa. In: Perchuk L.L., van Reenen, D.D., Varlamov, D.A., van Kal, S.M., Tabatabaeimanesh, Boshoff, R., (Eds.), Lithos, vol. 106, pp. 399-402.

Zeh, A., Klemd, R., Buhlmann, S., Barton, J.M., 2004. Pro- and retrograde P-T evolution of granulites of the Beit Bridge Complex (Limpopo Belt, South Africa); constraints from quantitative phase diagrams and geotectonic implications. Journal of Metamorphic Geology 22, 79-95.

Zeh, A., Holland, T.J.B., Klemd, R., 2005a. Phase relationships in grunerite-garnetbearing amphibolites in the system CFMASH, with applications to metamorphic rocks from the Central Zone of the Limpopo Belt, South Africa. Journal of Metamorphic Geology 23, 1-17.

Zeh, A., Klemd, R., Barton, J.M., 2005b. Petrological evolution in the roof of the highgrade metamorphic Central Zone of the Limpopo Belt, South Africa. Geological Magazine 142, 229-240.

Zeh, A., Gerdes, A., Klemd, R., Barton Jr., J.M., 2007. Archean to Proterozoic crustal evolution of the Limpopo Belt (South Africa/Botswana): constraints from combined U-Pb and Lu-Hf isotope zircon analyses. Journal of Petrology 48, 1605-1639. 